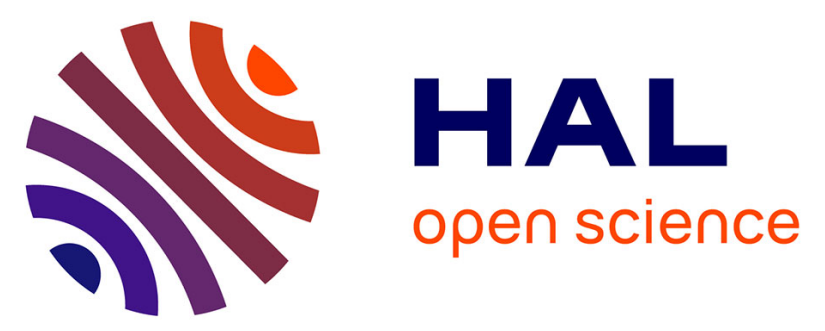

\title{
New flavonoid and stilbene derivatives from the fruits of Macaranga balansae
}

Huong Doan Thi Mai, Thang Pham Toan, Giap Tran Huu, Thanh Nguyen Le, Vu Thi Kim Oanh, Nguyen Thi Minh Hang, Huong Tran Thu, van Minh Chau, Marc Litaudon, van Cuong Pham

\section{To cite this version:}

Huong Doan Thi Mai, Thang Pham Toan, Giap Tran Huu, Thanh Nguyen Le, Vu Thi Kim Oanh, et al.. New flavonoid and stilbene derivatives from the fruits of Macaranga balansae. Natural Product Research, 2020, 34 (19), pp.2772-2778. 10.1080/14786419.2019.1587425 . hal-03354000

\author{
HAL Id: hal-03354000 \\ https://hal.science/hal-03354000
}

Submitted on 24 Sep 2021

HAL is a multi-disciplinary open access archive for the deposit and dissemination of scientific research documents, whether they are published or not. The documents may come from teaching and research institutions in France or abroad, or from public or private research centers.
L'archive ouverte pluridisciplinaire HAL, est destinée au dépôt et à la diffusion de documents scientifiques de niveau recherche, publiés ou non, émanant des établissements d'enseignement et de recherche français ou étrangers, des laboratoires publics ou privés. 


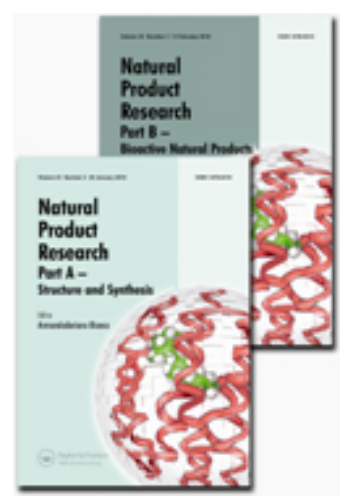

\section{New flavonoid and stilbene derivatives from the fruits of Macaranga balansae}

\begin{tabular}{|c|c|}
\hline Journal: & Natural Product Research \\
\hline Manuscript ID & GNPL-2018-3080 \\
\hline Manuscript Type: & Research Article \\
\hline $\begin{array}{r}\text { Date Submitted by the } \\
\text { Author: }\end{array}$ & 06-Dec-2018 \\
\hline Complete List of Authors: & $\begin{array}{l}\text { Thi Mai, Huong Doan; Institute of Marine Biochemistry - VAST, Organic } \\
\text { Synthesis; } \\
\text { Pham, Toan Thang; Hanoi University of Science and Technology, School } \\
\text { of Chemical Engineering; Ministry of Public Security, Institute of } \\
\text { Forensic Sciences } \\
\text { Tran, Huu Giap; Institute of Marine Biochemistry } \\
\text { Le, Nguyen Thanh; Institute of Marine Biochemistry, Advanced Center } \\
\text { for Bioorganic Chemistry; Graduate University of Science and } \\
\text { Technology, VAST } \\
\text { Vu, Thi Kim Oanh; Institute of Marine Biochemistry } \\
\text { Nguyen, Thi Minh Hang; Institute of Marine Biochemistry } \\
\text { Tran, Huong; Hanoi University of Science and Technology, } \\
\text { Chau, Van Minh; Institute of Marine Biochemistry, } \\
\text { Litaudon, Marc; Institut de Chimie des Substances Naturelles } \\
\text { Pham, Van Cuong; Institute of Marine Biochemistry, Vietnam Academy of } \\
\text { Science and Technology, }\end{array}$ \\
\hline Keywords: & $\begin{array}{l}\text { Macaranga balansae, Euphorbiaceae, prenylated flavonoid, stilbene, } \\
\text { cytotoxic activity }\end{array}$ \\
\hline
\end{tabular}

\section{SCHOLARONE" Manuscripts}




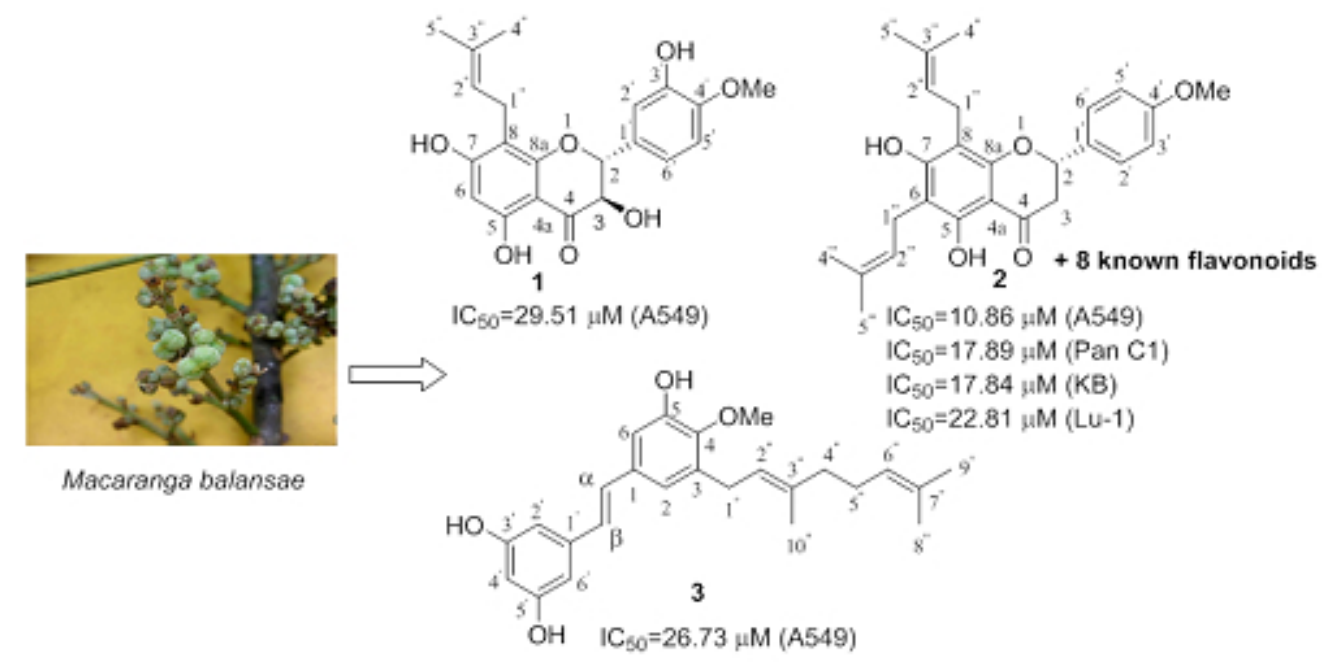




\section{New flavonoid and stilbene derivatives from the fruits of Macaranga balansae}

Huong Doan Thi Mai ${ }^{\mathrm{a}, \mathrm{b} *}$, Thang Pham Toan ${ }^{\mathrm{c}, \mathrm{d}}$, Giap Tran Huu ${ }^{\mathrm{a}}$, Thanh Nguyen Le a,b*, Vu Thi Kim Oanh ${ }^{a}$, Nguyen Thi Minh Hang ${ }^{a}$, Huong Tran Thu ${ }^{\mathrm{c}}$, Van Minh Chau $^{\mathrm{a}}$, Marc Litaudon ${ }^{\mathrm{e}}$, Van Cuong Pham ${ }^{\mathrm{a}, \mathrm{b}}$

${ }^{a}$ Advanced Center for Bioorganic Chemistry, Institute of Marine Biochemistry, Vietnam Academy of Science and Technology (VAST), 18 Hoang Quoc Viet, Caugiay, Hanoi, Vietnam;

${ }^{b}$ Graduate University of Science and Technology, VAST, 18 Hoang Quoc Viet, Caugiay, Hanoi, Vietnam;

cSchool of Chemical Engineering, Hanoi University of Science and Technology, 1 Dai Co Viet, Ha Ba Trung, Hanoi, Vietnam;

Institute of Forensic Sciences, Ministry of Public Security, 99 Nguyen Tuan, Thanh Xuan, Hanoi, Vietnam;

eInstitut de Chimie des Substances Naturelles, 91190 Gif-sur-Yvette Cedex, France;

${ }^{*}$ Corresponding author:

Assoc Prof. Dr. Huong Doan Thi Mai and Dr. Thanh Nguyen Le

Institute of Marine Biochemistry

Vietnam Academy of Science and Technology

18 Hoang Quoc Viet, Caugiay, Hanoi, Vietnam

Tel.: 842437564995

Fax: 84247917054

E-mail address: huongdm@imbc.vast.vn (Huong Doan Thi Mai);

lethanh@imbc.vast.vn (Thanh Nguyen Le) 


\section{New flavonoid and stilbene derivatives from the fruits of Macaranga balansae}

Two new prenylated flavonoids, 4'-methyl-8-prenyltaxifolin (1) and 6,8-diprenyl-4'methyl-narigenin (2) and a new geranylated stilbene, 4'-deprenyl-4-methoxymappain (3) together with eight known flavonoids (4-11) were isolated from the fruits of Macaranga balansae Gagnep. Their chemical structures were determined by means of spectroscopic methods including 1D, 2D NMR, and MS data. Compound 2 showed the highest cytotoxic activity against PanC1, A549, KB and LU-1 cell lines with $\mathrm{IC}_{50}$ values range from 7.89 to $22.91 \mu \mathrm{M}$.

Keywords: Macaranga balansae, Euphorbiaceae, prenylated flavonoid, stilbene, cytotoxic activity.

\section{Introduction}

Macaranga is a large genus of the Euphorbiaceae family, comprising more than 300 species and widely distributed in the tropical regions (Yang et al. 2015). In Vietnam, this genus known as "marang" has been used in the traditional medicine for the treatment of swellings, wounds and diarrhea (Vo 2012; Pham et al.1999). Previous studies on chemistry and pharmacology of Macaranga genus showed that their crude extracts and isolated compounds displayed interesting bioactivities such as antioxidant, antitumor, antimicrobial, and anti-inflammatory effects (Yoder et al. 2007, Magadula 2014). Flavonoids and stilbenes are major constituents and are most likely responsible for most of the activities found in the plants of this genus (Magadula 2014; Yang et al. 2015; Tanjung et al. 2018).

Macaranga balansae Gagnep is a native tree distributed in the central provinces of Vietnam. The chemical constituents of this plant have not been studied yet. In continuing of our study on anticancer effects of Macaranga genus in Vietnam (Péresse et al. 2017; Trinh et al. 2012), herein we report the isolation and structural elucidation of two new prenylated flavonoids, 4'-methyl-8prenyltaxifolin (1), 6,8-diprenyl-4'-methylnarigenin (2), one new geranylated stilbene, 4'deprenyl-4-methoxymappain (3) and eight known flavonoids (4-11) from the fruits of $M$. balansae (Fig. 1). Their chemical structures were established based on IR, NMR, and HR-ESIMS spectra analysis. All newly isolated compounds were evaluated for cytotoxic activity.

\section{Results and discussions}

Compound 1 was isolated as colourless solid. The molecular formula of $\mathrm{C}_{21} \mathrm{H}_{22} \mathrm{O}_{7}$ was determined from the peak at $m / z 385.1285[\mathrm{M}-\mathrm{H}]^{-}$in the negative HR-ESI-MS of $\mathbf{1}$. The IR spectrum showed hydroxyl and carbonyl absorptions at 3443 and $1634 \mathrm{~cm}^{-1}$. The ${ }^{1} \mathrm{H}-\mathrm{NMR}$ 
spectrum of 1 showed characteristic signals of a flavanonol with an $\mathrm{ABX}$ aromatic system of $\mathrm{B}$ $\operatorname{ring}\left(\delta_{\mathrm{H}} 7.09\left(\mathrm{~d}, J=2.0 \mathrm{~Hz}, \mathrm{H}-2^{\prime}\right), 7.02\left(\mathrm{dd}, J=8.5,2.0 \mathrm{~Hz}, \mathrm{H}-6^{\prime}\right), 6.92\left(\mathrm{~d}, J=8.0 \mathrm{~Hz}, \mathrm{H}-5^{\prime}\right)\right.$, two oxymethine protons $\left[\delta_{\mathrm{H}} 4.96(\mathrm{~d}, J=12.0 \mathrm{~Hz})\right.$ and $\left.4.48(\mathrm{~d}, J=12.0 \mathrm{~Hz})\right]$ of C-ring, and signals of a prenyl group at $\delta_{\mathrm{H}} 5.18(1 \mathrm{H}, \mathrm{t}, J=7.0 \mathrm{~Hz}), 3.19(2 \mathrm{H}, \mathrm{d}, J=7.0 \mathrm{~Hz}), 1.64(3 \mathrm{H}, \mathrm{s})$, and $1.57(3 \mathrm{H}$, s). In addition, one methoxy group was observed at $\delta_{\mathrm{H}} 3.91$ (s). The ${ }^{13} \mathrm{C}-\mathrm{NMR}$ spectrum of 1 showed the signals of 21 carbon including fifteen carbons of flavanonol and five carbons of a prenyl and one methoxy carbon $\left(\delta_{\mathrm{C}} 56.0\right)$. The above evidence suggested that the structure of 1 was similar to 8-prenyltaxifolin except for the presence of methoxy group at C-4' (Chen et al. $2013)$. The HMBC correlations from H-2' $\left(\delta_{\mathrm{H}} 7.09\right) / \mathrm{H}-6^{\prime}\left(\delta_{\mathrm{H}} 7.02\right)$ to $\mathrm{C}-4^{\prime}\left(\delta_{\mathrm{C}} 147.7\right)$; from H-5' $\left(\delta_{\mathrm{H}} 6.92\right)$ to $\mathrm{C}-3^{\prime}\left(\delta_{\mathrm{C}} 145.9\right)$; from methoxy protons $\left(\delta_{\mathrm{H}} 3.91\right)$ to $\mathrm{C}-4^{\prime}\left(\delta_{\mathrm{C}} 147.7\right)$ suggested the positions of hydroxy and methoxy groups at C-3" and C-4", respectively. The HMBC correlations between H-2" $\left(\delta_{\mathrm{H}} 5.18\right)$ to $\mathrm{C}-8\left(\delta_{\mathrm{C}} 108.7\right) / \mathrm{C}-1 "{ }^{\prime \prime}\left(\delta_{\mathrm{C}} 21.5\right) / \mathrm{C}-4 " 4^{\prime \prime}\left(\delta_{\mathrm{C}} 25.7\right) / \mathrm{C}-5^{\prime \prime}\left(\delta_{\mathrm{C}}\right.$ $17.6)$; between H-1" $\left(\delta_{\mathrm{H}} 3.19\right)$ to $\mathrm{C}-7\left(\delta_{\mathrm{C}} 165.5\right) / \mathrm{C}-8\left(\delta_{\mathrm{C}} 147.7\right) / \mathrm{C}-8 \mathrm{a}\left(\delta_{\mathrm{C}} 159.9\right)$ suggested the position of prenyl group at C-8 (Fig. S1). The 2,3-trans configuration was assigned from the large coupling constant value of H-2 and H-3 $(J=12.0 \mathrm{~Hz})$. In addition, the absolute configuration at C-2 were determined to be $R$ from the positive Cotton effect at $340 \mathrm{~nm}$ and the negative one at $296 \mathrm{~nm}$ in the CD spectrum, similar to those of related compound (Sasaki et al. 2014; Sutthivaiyakit et al. 2009). Thus, the absolute configuration of 1 was characterised as $2 R, 3 R$ (Wu et al.2003; Slade et al. 2005). Compound 1 was newly identified as 4'-methyl-8prenyltaxifolin.

Compound 2 was obtained as pale yellow solid. Its HR-ESI-MS ion at $\mathrm{m} / z 423.2179$ $[\mathrm{M}+\mathrm{H}]^{+}$corresponding to the molecular formula of $\mathrm{C}_{26} \mathrm{H}_{31} \mathrm{O}_{5}$. The ${ }^{1} \mathrm{H}-$ and ${ }^{13} \mathrm{C}-\mathrm{NMR}$ data of compound 2 were very similar to those of lonchocarpol A (Meragelman et al. 2011). The only difference is $\mathbf{2}$ containing a methoxy group in the NMR spectrum. In the ${ }^{1} \mathrm{H}-\mathrm{NMR}$ spectrum, the signals at $\delta_{\mathrm{H}} 5.34(\mathrm{dd}, J=12.5,3.0 \mathrm{~Hz}), 3.07(\mathrm{dd}, J=17.5,12.5 \mathrm{~Hz})$ and $2.82(\mathrm{dd}, J=17.0,3.0$ $\mathrm{Hz})$, suggested the presence of flavanone skeleton. In addition, the signals at $\delta_{\mathrm{H}} 3.30(2 \mathrm{H}, \mathrm{d}, J=$ $\left.7.0 \mathrm{~Hz}, \mathrm{H}-1^{\prime \prime}\right), 5.21\left(1 \mathrm{H}, \mathrm{t}, J=7.0 \mathrm{~Hz}, \mathrm{H}-2^{\prime \prime}\right), 1.70\left(3 \mathrm{H}, \mathrm{s}, \mathrm{H}-4^{\prime \prime}\right), 1.71\left(3 \mathrm{H}, \mathrm{s}, \mathrm{H}-5^{\prime \prime}\right), 3.35$ (2H, d, $\left.J=7.0 \mathrm{~Hz}, \mathrm{H}-1^{\prime \prime \prime}\right), 5.25$ (1H, t, $\left.J=7.0 \mathrm{~Hz}, \mathrm{H}-2^{\prime \prime \prime}\right), 1.81$ (3H, s, H-4"'), 1.74 (3H, s, H-5'"') were assigned to two prenyl groups. The HMBC correlations between $\mathrm{H}-1$ " and C-7 $\left(\delta_{\mathrm{C}} 162.2\right) / \mathrm{C}-8$ $\left(\delta_{\mathrm{C}} 106.4\right) / \mathrm{C}-8 \mathrm{a}\left(\delta_{\mathrm{C}} 157.7\right)$; between H-1"' and C-5 $\left(\delta_{\mathrm{C}} 159.3\right) / \mathrm{C}-6\left(\delta_{\mathrm{C}} 107.2\right) / \mathrm{C}-7\left(\delta_{\mathrm{C}} 162.2\right)$ confirming the positions of prenyl groups at C-8 and C-6. The methoxy group at C-4' were confirmed by HMBC correlation from the methoxy group $\left(\delta_{\mathrm{H}} 3.83\right)$ to $\mathrm{C}-4^{\prime}\left(\delta_{\mathrm{C}} 159.8\right)$ (Fig. S1). Consequently, compound 2 was identified as 6,8-diprenyl-4'-methylnarigenin.

Compound $\mathbf{3}$ was obtained as pale yellow solid. Its molecular 
formula was determined as $\mathrm{C}_{25} \mathrm{H}_{30} \mathrm{O}_{4}$ by HR-ESI-MS $\left(\mathrm{m} / \mathrm{z}\right.$ 395.2222, $[\mathrm{M}+\mathrm{H}]^{+}$, calcd. for 395.2222). The chemical structure of $\mathbf{3}$ is similar to 4'-deprenyl-mappain isolated from African propolis (Almutairi et al. 2014). The only difference is $\mathbf{3}$ containing a methoxy group $\left(\delta_{\mathrm{H}} 3.80\right.$, $\left.\delta_{\mathrm{C}} 61.3\right)$ in the NMR spectrum. The ${ }^{1} \mathrm{H}-\mathrm{NMR}$ spectrum of $\mathbf{3}$ showed signals of a geranylated trans-stilbene $(J=16.0 \mathrm{~Hz})$ with two olefinic protons observed at $\delta_{\mathrm{H}} 6.90(\mathrm{~d}, J=16.0 \mathrm{~Hz}, \mathrm{H}-\alpha)$ and $6.80(\mathrm{~d}, J=16.0 \mathrm{~Hz}, \mathrm{H}-\beta)$. The HMBC correlations from $\mathrm{H}-\beta\left(\delta_{\mathrm{H}} 6.80\right)$ to $\mathrm{C}-1^{\prime}\left(\delta_{\mathrm{C}} 133.8\right), \mathrm{C}-$ $2^{\prime}\left(\mathrm{C}-6^{\prime}\right)\left(\delta_{\mathrm{C}} 106.1\right)$; from H-2' $\left(\mathrm{H}-6^{\prime}\right)\left(\delta_{\mathrm{H}} 6.53\right)$ to $\mathrm{C}-3^{\prime}\left(\mathrm{C}-5^{\prime}\right)\left(\delta_{\mathrm{C}} 156.9\right)$ and $\mathrm{C}-4^{\prime}\left(\delta_{\mathrm{C}} 102.1\right)$ suggested the positions of two hydroxy groups at C-3' and C-5'. The HMBC correlations from H$6\left(\delta_{\mathrm{H}} 6.96\right)$ to $\mathrm{C}-\alpha\left(\delta_{\mathrm{C}} 129.1\right) / \mathrm{C}-4\left(\delta_{\mathrm{C}} 145.0\right) / \mathrm{C}-5\left(\delta_{\mathrm{C}} 148.9\right)$; from H-2 $\left(\delta_{\mathrm{H}} 6.80\right)$ to $\mathrm{C}-\alpha\left(\delta_{\mathrm{C}}\right.$ $129.1) / \mathrm{C}-3\left(\delta_{\mathrm{C}} 134.8\right)$; and from methoxy group $\left(\delta_{\mathrm{H}} 3.80\right)$ to $\mathrm{C}-4\left(\delta_{\mathrm{C}} 145.0\right)$ confirmed the position of methoxy and hydroxy groups at C-4 and C-5, respectively. The geranyl group was characterized by three methyl groups at $\delta_{\mathrm{H}} 1.74,1.59$, and $1.66(3 \mathrm{H}$, each, s); three methylene signals at $\delta_{\mathrm{H}} 3.37(\mathrm{~d}, J=6.5 \mathrm{~Hz}), 2.12(7, J=8.0 \mathrm{~Hz})$ and $2.07(\mathrm{t}, J=7.5 \mathrm{~Hz})$; two olefinic protons at $\delta_{\mathrm{H}} 5.30(\mathrm{t}, J=7.0 \mathrm{~Hz})$ and $5.10(\mathrm{~d}, J=6.0 \mathrm{~Hz})$. The locations of geranyl at C-3 of benzene ring was determined by the HMBC correlations from $\mathrm{H}-1^{\prime \prime}\left(\delta_{\mathrm{H}} 3.37\right)$ to $\mathrm{C}-2\left(\delta_{\mathrm{C}}\right.$ $120.5) / \mathrm{C}-3\left(\delta_{\mathrm{C}} 134.8\right) / \mathrm{C}-4\left(\delta_{\mathrm{C}} 145.0\right)$; from $\mathrm{H}-2\left(\delta_{\mathrm{H}} 6.80\right)$ to $\mathrm{C}-1 " \prime\left(\delta_{\mathrm{C}} 28.0\right)($ Fig. S1). Thus, the structure of compound $\mathbf{3}$ was elucidated as 4'-deprenyl-4-methoxymappain.

The known compounds were elucidated as 8-prenylisosacuranetin (4) (Chen et al. 2013), lonchocarpol A (5) (Meragelman et al. 2011), 6,8-diprenylaromadendrin (Meragelman et al. 2011) (6), propolin I (7) (Huang et al. 2010), exiguaflavanone K (8) (Linuma et al. 1994), 8prenylnarigenin (9) (Chen et al. 2013), 5,7,4 '-trihydroxy-8-(2,3-dihydroxy-3methylbutyl)flavanone (10) (Cano et al. 2006), and macarecurvatin A (11) (Tanjung et al. 2014). Their chemical structures were determined by NMR spectra and in comparison with previously reported values. Notably, propolin I (7) have been only isolated from Taiwanese propolis, not from any plant (Huang et al. 2010).

Compounds 1-3 were evaluated for their cytotoxicity against seven cancer cell lines including A549, Hela, Pan C1, MCF-7, Hep3B, KB and Lu-1 using MTT method (Mosmann 1983). As the results, compound 2 showed significant cytotoxicity against $\mathrm{A} 549$, PanC1, KB and Lu-1 cancer cell lines with $\mathrm{IC}_{50}$ values range from 7.89 to $22.81 \mu \mathrm{M}$ while compound 1 and 3 displayed the moderate activity against A549, Hela, Pan C1, MCF-7, Hep3B cell lines ( $\mathrm{IC}_{50}$ values range from 26.73 to $\left.79.43 \mu \mathrm{M}\right)$ (Table $\mathrm{S} 1$ ). 


\section{Experimental}

\subsection{General experimental procedures}

Optical rotations were recorded on a Polax-2L polarimeter in $\mathrm{CHCl}_{3}$. HR-ESI-MS were recorded on a FT-ICR 910-MS TQFTMS-7T and a VARIAN 910 mass spectrometers. IR spectra were recorded on a Nicolet Impact 410 FT-IR spectrometer, UV spectrum on a UV-1601 spectrometer, and NMR spectra on a Bruker AM500 MHz spectrometer operating at 125.76 $\mathrm{MHz}$ for ${ }^{13} \mathrm{C} \mathrm{NMR}$, and at $500.13 \mathrm{MHz}$ for ${ }^{1} \mathrm{H}-\mathrm{NMR} .{ }^{1} \mathrm{H}-\mathrm{NMR}$ chemical shifts were referenced to $\mathrm{CDCl}_{3}$ at $7.27 \mathrm{ppm}$, and ${ }^{13} \mathrm{C}$-NMR chemical shifts to the central peak of $\mathrm{CDCl}_{3}$ at $77.0 \mathrm{ppm}$.

\subsection{Plant material}

The fruits of M. balansae Gagnep. were collected at Tuyen Hoa, Quang Binh, in 2011, July and identified by Dr. Nguyen The Cuong, Institute of Ecology and Biological Resources, Vietnam Academy of Science \& Technology. A voucher specimen (VN-2223) was deposited at the Herbarium of the Institute of Ecology and Biological Resources, VAST.

\subsection{Extraction and isolation}

The powdered, dried fruits of M. balansae Gagnep. $(200 \mathrm{~g})$ was extracted with ethyl acetate (1 L $\mathrm{x} 4$ times, 24h/time) at room temperature. The combined extracts were evaporated in vacuo to obtain ethyl acetate residue ( $20 \mathrm{~g})$. The ethyl acetate residue was purified by chromatography column (CC) on silica gel and eluted with solvent gradient of $n$-hexane/acetone to afford 17 fractions (E1-E17). Fraction E4 (0.27 g) was separated on silica gel CC, eluted with $n$-hexane$\mathrm{CH}_{2} \mathrm{Cl}_{2}(8: 2, \mathrm{v} / \mathrm{v})$ to yield $2(22 \mathrm{mg})$. Fraction E12 $(5 \mathrm{~g})$ was recrystallized in $\mathrm{CH}_{2} \mathrm{Cl}_{2}$ to give 4 (40 mg). Fraction E12 (3.57 g) was subjected to silica gel CC and eluted with $n$-hexane/ethyl acetate $(7: 3, \mathrm{v} / \mathrm{v})$ to give 7 sub-fractions E12.1-E12.7. Sub-fraction E12.1 (0.2 g) was separated by CC on silica gel, eluting with $n$-hexane-ethyl acetate $(19: 1, \mathrm{v} / \mathrm{v})$ to afford $5(9 \mathrm{mg})$. Subfraction E12.5 (0.5 g) was chromatographed on silica gel column and eluted with $n$-hexane/ethyl acetate $(9: 1, \mathrm{v} / \mathrm{v})$ to give 3 sub-subfractions E12.5.1-E.12.5.3. Fraction E.12.5.3 (80 mg) was purified on silica gel CC using $n$-hexane/acetone $(8: 2, \mathrm{v} / \mathrm{v})$ as eluent to yield $6(8 \mathrm{mg})$. Fraction E13 (1.4 g) was purified on Sephadex LH-20 CC, eluted with $\mathrm{MeOH} / \mathrm{CH}_{2} \mathrm{Cl}_{2}(8: 2, \mathrm{v} / \mathrm{v})$ to afford 2 sub-fractions E13.1-E13.2. Sub-fraction E13.2 (0.5 g) was separated on silica gel CC and eluting was performed with $n$-hexane/acetone $(7: 3, \mathrm{v} / \mathrm{v})$ yield 7. Fraction E14 (1.6 g) was chromatographed on silica gel column eluting with $\mathrm{CH}_{2} \mathrm{Cl}_{2} /$ acetone $(9: 1, \mathrm{v} / \mathrm{v})$ to give 2 subfractions E14.1-E14.2. Compound 8 (9 $\mathrm{mg})$ and $9(4.5 \mathrm{mg})$ was obtained from the E14.1 and E14.2 sub-fractions, respectively by recrystallization in $\mathrm{CH}_{2} \mathrm{Cl}_{2}$. Fraction E17 (2.4 g) was separated by Sephadex $\mathrm{CC}$ and eluted with $\mathrm{MeOH} / \mathrm{CH}_{2} \mathrm{Cl}_{2}(8: 2$, v/v) to give 3 sub-fractions 
E17.1-E17.3. Sub-fraction E17.1 (60 mg) was purified with silica gel CC and eluted with $\mathrm{CH}_{2} \mathrm{Cl}_{2} /$ acetone $(8: 2, \mathrm{v} / \mathrm{v})$ to afford 2 sub-subfraction E12.1.1-E17.1.2. Fraction E17.1.1 (18 mg) was purified on Sephadex CC, eluting was performed with $\mathrm{MeOH} / \mathrm{CH}_{2} \mathrm{Cl}_{2}(8: 2, \mathrm{v} / \mathrm{v})$ to yield $\mathbf{1 0}$ $(2.5 \mathrm{mg})$. Subfraction E17.1.2 (22 $\mathrm{mg})$ was separated by preparative silica gel TLC using $\mathrm{CH}_{2} \mathrm{Cl}_{2} /$ acetone $(19: 1, \mathrm{v} / \mathrm{v})$ as eluent to give compound 1 (4.5 mg). Sub-fraction E17.3 (53 mg) was separated on silica gel $\mathrm{CC}$ and eluted with $\mathrm{CH}_{2} \mathrm{Cl}_{2} /$ acetone $(9: 1, \mathrm{v} / \mathrm{v})$ to yield $11(26 \mathrm{mg})$ and $3(8.5 \mathrm{mg})$.

\subsubsection{4'-Methyl-8-prenyltaxifolin (1)}

Colorless solid; $[\alpha]_{\mathrm{D}}^{25}-20.0\left(c 0.04, \mathrm{CHCl}_{3}\right)$; UV (MeOH) $\lambda_{\max } 295,342 \mathrm{~nm}$; FT-IR (KBr) $v_{\max }$ : 3443, 2929, 1634, 1444, $1384 \mathrm{~cm}^{-1} ;{ }^{1} \mathrm{H}-\mathrm{NMR}$ and ${ }^{13} \mathrm{C}-\mathrm{NMR}$ data see Table 1; HR-ESI-MS: $\mathrm{m} / z$ $385.1285[\mathrm{M}-\mathrm{H}]^{-}$(calcd. for $\mathrm{C}_{21} \mathrm{H}_{21} \mathrm{O}_{7}, 385.1287$ ).

\subsubsection{6,8-Diprenyl-4'-methyl-narigenin (2)}

Pale yellow oil; $[\alpha]_{\mathrm{D}}^{24}-23.6\left(c\right.$ 0.15, $\left.\mathrm{CHCl}_{3}\right)$; UV (MeOH) $\lambda_{\max } 295,342 \mathrm{~nm}$; FT-IR (KBr) $v_{\max }$ : $3438,2917,2852,1633,1516,1448,1342,1376,1306,1253,1178,1118 \mathrm{~cm}^{-1} ;{ }^{1} \mathrm{H}-$ and ${ }^{13} \mathrm{C}-$ NMR data see Table 1; HR-ESI-MS: $m / z 423.2179[\mathrm{M}+\mathrm{H}]^{+}\left(\right.$calcd. for $\mathrm{C}_{26} \mathrm{H}_{31} \mathrm{O}_{5}, 423.2171$ ).

\subsubsection{4'-Deprenyl-4-methoxymappain (3)}

Pale yellow solid; UV (MeOH) $\lambda_{\max }$ 305, 340 nm; FT-IR (KBr) $v_{\max }$ : 3443, 2929, 1628, 1445, 1382, 1144, 1001, $847 \mathrm{~cm}^{-1} ;{ }^{1} \mathrm{H}$ - and ${ }^{13} \mathrm{C}-\mathrm{NMR}$ data see Table 1; HR-ESI-MS: $\mathrm{m} / \mathrm{z} 395.2222$ [M $+\mathrm{H}^{+}$(calcd. for $\mathrm{C}_{25} \mathrm{H}_{30} \mathrm{O}_{4}, 395.2222$ ).

\subsection{Cytotoxic activity assay}

The cytotoxicity assays were carried out in triplicate in 96-well microtiter plates against A549, Hela, PanC1, MCF-7, Hep3B, KB and Lu-1 cell lines. Cells were maintained in Dulbecco's D-MEM medium, supplemented with 10\% fetal calf serum, L-glutamine $(2 \mathrm{mM})$, penicillin $\mathrm{G}(100 \mathrm{UI} / \mathrm{mL})$, streptomycin $(100 \mu \mathrm{g} / \mathrm{mL})$ and gentamicin $(10 \mu \mathrm{g} / \mathrm{mL})$. Stock solutions of compounds were prepared in $\mathrm{DMSO} / \mathrm{H}_{2} \mathrm{O}$ (1/9), and the cytotoxicity assays were carried out in 96-well microtiter plates against cancer or normal cells $\left(3 \times 10^{3}\right.$ cells $\left./ \mathrm{mL}\right)$ using a modification of the published method (Mosmann $\mathrm{T}$. 1983). After $72 \mathrm{~h}$ incubation at $37^{\circ} \mathrm{C}$ in air/ $\mathrm{CO}_{2}$ (95:5) with or without test compounds, cell growth was estimated by colorimetric measurement of stained living cells by neutral red. Optical density was determined at $540 \mathrm{~nm}$ with a Titertek Multiskan photometer. The $\mathrm{IC}_{50}$ value was defined as the concentration of sample necessary to inhibit the cell growth to $50 \%$ of the control. Ellipticine was used as a reference compound. 


\section{Conclusion}

Two new flavonoids, 4'-methyl-8-prenyltaxifolin (1) and 6,8-diprenyl-4'-methyl-narigenin (2) and a new geranylated stilbene 4'-deprenyl-4-methoxymappain (3) together with eight known compounds (4-11) were isolated from the fruits of M. balansae Gagnep. collected in Quang Binh province, Vietnam. Compound 2 exhibited significant cytotoxicity against A549, PanC1, KB and Lu-1 cancer cell lines with $\mathrm{IC}_{50}$ values range from 7.89 to $22.81 \mu \mathrm{M}$.

\section{Supplementary material}

HR-ESI-MS, 1D, 2D NMR spectra and cytotoxicity results of compounds $\mathbf{1 - 3}$, are available as Supporting Information.

\section{Disclosure statement}

No potential conflict of interest was reported by the authors.

\section{Funding}

The Centre National de la Recherche Scientifique (CNRS, France) is gratefully acknowledged for the Franco-Vietnamese Cooperation Program and The Ministry of Science and Technology of Vietnam for financial support [Grant number ĐTĐLCN.14/16].

\section{References}

Almutairi S, Eapen B, Chundi SM, Akhalil A, Siheri W, Clements C, Fearnley J, Watson DG, Edrada-Ebel R. 2014. New anti-trypanosomal active prenylated compounds from African propolis. Phytochemistry Lett. 10:35-39.

Cano A, Espinoza M, Ramos CH, Delgado G. 2006. New prenylated flavanones from Esenbeckia berlandieri ssp. acapulcensis. J Mex Chem Soc. 50:71-75.

Chen R, Liu X, Zou J, Yin Y, Ou B, Li J, Wang R, Xie D, Zhang P, Dai J. 2013. Regio-and stereospecific prenylation of flavonoids by Sophora flavescens prenyltransferase. Adv Synth Catal. 355: 1817-1828.

Huang CY, Chen CN, Huang WJ, Chi LL, Chen PY, Lin CW. 2010. Prenyl flavanone compounds and uses thereof. US2010/0144856A1

Linuma M, Yokoyama J, Ohyama M, Tanaka T, Ruangrungsi N. 1994. Eight phenolic compounds in root of Sophora exigua. Phytochemistry. 35:785-789.

Magadula JJ. 2014. Phytochemistry and pharmacology of the genus Macaranga: A review. J Med Plants Res. 8:489-503.

Meragelman KM, McKee TC, Boyd MR. 2001. Anti-HIV prenylated flavonoids from Monotes africanus. J Nat Prod. 64:546-548. 
Mosmann T. 1983. Rapid colorimetric assay for cellular growth and survival: application to proliferation and cytotoxicity assays. J Immunol Methods. 65: 55-63.

Péresse T, Jézéquel G, Allard PM, Pham VC, Huong DTM, Blanchard F, Bignon R, Levaique H, Wolfender JL, Litaudon M, Roussi F. 2017. Cytotoxic prenylated stilbenes isolated from Macaranga tanarius. J Nat Prod. 80:2684-2691.

Pham HH.1999. An illustrated the flora of Vietnam. NXB Tre: Ho Chi Minh, Vietnam. Vol. II

Sasaki H, Shibata H, Imabayashi K, Takaishi Y, Kashiwada Y. 2014. Prenylated flavonoids from the stems and leaves of Desmodium caudatum and evaluation of their inhibitory activity against the film-forming growth of Zygosaccharomyces rouxii F51. J Agric Food Chem.62:6345-6353.

Slade D, Ferreira D, Marais JPJ. 2005. Circular dichroism, a powerful tool for the assessment of absolute configuration of flavonoids. Phytochemistry. 66:2177-2215.

Sutthivaiyakit S, Thongnak O, Lhinhatrakool T, Yodchun O, Srimark R, Dowtaisong P, Chuankamnerdkarn M. 2009. Cytotoxic and antimycobacterial prenylated flavonoids from the roots of Eriosema chinense. J Nat Prod.72:1092-1096.

Tanjung M, Tjahjandarie TS. 2014. Dihydroflavonols from the leaves of Macaranga recurvata and their cytotoxic and antioxidant activities. J Chem Pharm Res. 6:90-95

Tanjung M, Juliawaty LD, Hakim EH, Syah YM. 2018. Flavonoid and stilbene derivatives from Macaranga trichocarpa. Fitoterapia. 126:74-77

Trinh TTV, Huong DTM, Pham VC, Litaudon M, Dumontet V, Gueritte F, Nguyen VH, and Chau VM. 2012. Acetylcholinesterase Inhibitors from the Leaves of Macaranga kurzii. J Nat Prod. 75:212-215

Yang DS, Peng WB, Yang YP, Liu KC, Li XL, Xiao WL. 2015. Cytotoxic prenylated flavonoids from Macaranga indica. Fitoterapia. 103:187-191

Yoder BJ, Cao S, Norris A, Miller JS, Ratovoson F, Razafitsalama J, Andriantsiferana R, Rasamison VE, Kingston DGI. 2007. Antiproliferative prenylated stilbenes and flavonoids from Macaranga alnifolia from the Madagascar rainforest. J Nat Prod. 70:342-346

Vo VC. 2012. Dictionary of Vietnamese medicinal plants. Vol. 1. Hanoi: Medical Publisher, p. 69-71.

$\mathrm{Wu}$ TS, Hsu MY, Kuo PC, Sreenivasulu B, Damu AG, Su CR, Li CY, Chang HC.2003. Constituents from the leaves of Phellodendron amurense var. wilsonii and their bioactivity. J Nat Prod. 66:1207-1211. 
<smiles></smiles><smiles>[3H]C(C)=C[I-]c1c(O)c([CH-]C=C(C)C)c2c(c1O)C(=O)C[C@@H](c1ccc(OC)cc1)O2</smiles><smiles>[R]c1ccc([C@@H]2CC(=O)c3c(O)cc(O)c(CC=C(C)C)c3O2)cc1[R]</smiles><smiles>CC(C)=CCc1c(O)c(CC=C(C)C)c2c(c1O)C(=O)C[C@@H](c1ccc(O)cc1)O2</smiles><smiles>COc1c(O)cc(C=Cc2cc(O)cc(O)c2)cc1CC=C(C)CCC=C(C)C</smiles>

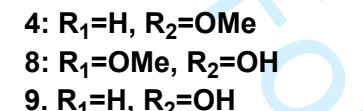

9. $\mathrm{R}_{1}=\mathrm{H}, \mathrm{R}_{2}=\mathrm{OH}$<smiles>[3H]C(=O)C[C@H](Oc1cc(O)c(C/C=C(\C)CC/C=C(\C)CCC=C(C)C)c(O)c1)c1cccc(O)c1</smiles><smiles>[R2]O[R2](=O)O</smiles>

Figure 1. Chemical structures of 1-11 from M. balansae 
Table 1. The NMR spectral data of compounds 1-3

\begin{tabular}{|c|c|c|c|c|c|c|c|}
\hline \multirow{2}{*}{ No } & \multicolumn{2}{|r|}{$\mathbf{1}^{\mathrm{a}}$} & \multicolumn{2}{|r|}{$2^{b}$} & \multirow{2}{*}{ No } & \multicolumn{2}{|r|}{$3^{\mathrm{b}}$} \\
\hline & $\delta_{\mathrm{C}}$ & $\delta_{\mathrm{H}}(J$ in $\mathrm{Hz})$ & $\delta_{\mathrm{C}}$ & $\delta_{\mathrm{H}}(J$ in $\mathrm{Hz})$ & & $\delta_{\mathrm{C}}$ & $\delta_{\mathrm{H}}(J$ in $\mathrm{Hz})$ \\
\hline 1 & & & & & 1 & 140.0 & - \\
\hline 2 & 83.1 & $4.96 \mathrm{~d}(12.0)$ & 78.5 & $5.34 \mathrm{dd}(3.0,12.5)$ & 2 & 120.5 & $6.80 \mathrm{~d}(1.5)$ \\
\hline 3 & 72.5 & $4.48 \mathrm{~d}(12.0)$ & 43.2 & $\begin{array}{l}3.07 \mathrm{dd}(12.5,17.0) \\
2.82 \mathrm{dd}(3.0,17.0)\end{array}$ & 3 & 134.8 & - \\
\hline 4 & 196.4 & - & 196.5 & - & 4 & 145.0 & - \\
\hline $4 a$ & 100.5 & - & 102.8 & - & 5 & 148.9 & - \\
\hline 5 & 161.2 & - & 159.3 & - & 6 & 110.7 & $6.96 \mathrm{~d}(1.5)$ \\
\hline 6 & 96.2 & $6.02 \mathrm{~s}$ & 107.2 & - & $1^{\prime}$ & 133.8 & - \\
\hline 7 & 165.5 & - & 162.2 & - & $2^{\prime}$ & 106.1 & $6.53 \mathrm{~d}(2.0)$ \\
\hline 8 & 108.7 & - & 106.4 & - & $3^{\prime}$ & 156.9 & - \\
\hline $8 \mathrm{a}$ & 159.9 & - & 157.7 & - & $4^{\prime}$ & 102.1 & $6.25 \mathrm{br} \mathrm{s}$ \\
\hline $1^{\prime}$ & 129.9 & - & 131.0 & & $5^{\prime}$ & 156.9 & - \\
\hline $2^{\prime}$ & 114.1 & $7.09 \mathrm{~d}(2.0)$ & 127.4 & $7.37 \mathrm{~d}(8.5)$ & $6^{\prime}$ & 106.1 & $6.53 \mathrm{~d}(2.0)$ \\
\hline $3^{\prime}$ & 145.9 & - & 114.0 & $6.95 \mathrm{~d}(8.5)$ & $\alpha$ & 129.1 & $6.90 \mathrm{~d}(16.0)$ \\
\hline $4^{\prime}$ & 147.7 & - & 159.8 & - & $\beta$ & 127.5 & $6.80 \mathrm{~d}(16.0)$ \\
\hline $5^{\prime}$ & 110.9 & $6.92 \mathrm{~d}(8.5)$ & 114.0 & $6.95 \mathrm{~d}(8.5)$ & $1^{\prime \prime}$ & 28.0 & $3.37 \mathrm{~d}(7.0)$ \\
\hline $6^{\prime}$ & 119.6 & $7.02 \mathrm{dd}(2.0,8.5)$ & 127.4 & $7.37 \mathrm{~d}(8.5)$ & $2^{\prime \prime}$ & 122.3 & $5.30 \mathrm{t}(7.0)$ \\
\hline $1^{\prime \prime}$ & 21.5 & $3.19 \mathrm{~d}(7.0)$ & 21.2 & $3.30 \mathrm{~d}(7.0)$ & $3^{\prime \prime}$ & 136.6 & - \\
\hline $2^{\prime \prime}$ & 122.2 & $5.18 \mathrm{t}(7.0)$ & 122.0 & $5.21 \mathrm{t}(7.0)$ & $4^{\prime \prime}$ & 39.6 & $2.07 \mathrm{t}(7.5)$ \\
\hline $3^{\prime \prime}$ & 131.8 & - & 133.8 & - & $5^{\prime \prime}$ & 26.6 & $2.12(\mathrm{~m})$ \\
\hline $4^{\prime \prime}$ & 25.7 & $1.64 \mathrm{~s}$ & 17.9 & $1.70 \mathrm{~s}$ & $6^{\prime \prime}$ & 124.1 & $5.10 \mathrm{t}(6.0)$ \\
\hline $5^{\prime \prime}$ & 17.6 & $1.57 \mathrm{~s}$ & 25.8 & $1.71 \mathrm{~s}$ & $7^{\prime \prime}$ & 131.7 & - \\
\hline $1^{\prime \prime \prime}$ & & & 21.9 & $3.35 \mathrm{~d}(7.0)$ & $8^{\prime \prime}$ & 25.7 & $1.74 \mathrm{~s}$ \\
\hline $2^{\prime \prime \prime}$ & & & 121.8 & $5.25 \mathrm{t}(7.0)$ & $9^{\prime \prime}$ & 17.7 & $1.59 \mathrm{~s}$ \\
\hline $3^{\prime \prime \prime}$ & & & 134.6 & - & $10^{\prime \prime}$ & 16.2 & $1.66 \mathrm{~s}$ \\
\hline $4^{\prime \prime \prime}$ & & & 25.8 & $1.74 \mathrm{~s}$ & $\mathrm{OMe}$ & 61.3 & $3.80 \mathrm{~s}$ \\
\hline $5^{\prime \prime \prime}$ & & & 17.8 & $1.81 \mathrm{~s}$ & & & \\
\hline $\mathrm{OMe}$ & 56.0 & $3.91 \mathrm{~s}$ & 55.3 & $3.83 \mathrm{~s}$ & & & \\
\hline $5-\mathrm{OH}$ & & & & $12.33 \mathrm{~s}$ & & & \\
\hline 7-OH & & & & $6.36 \mathrm{~s}$ & & & \\
\hline
\end{tabular}

${ }^{a}$ Measured in $\mathrm{CDCl}_{3}$ and $\mathrm{CD}_{3} \mathrm{OD},{ }^{b}$ Measured in $\mathrm{CDCl}_{3}$ 


\section{New flavonoid and stilbene derivatives from the fruits of Macaranga balansae}

Huong Doan Thi Mai ${ }^{\mathrm{a}, \mathrm{b} *}$, Thang Pham Toan ${ }^{\mathrm{c}, \mathrm{d}}$, Giap Tran Huu ${ }^{\mathrm{a}}$, Thanh Nguyen Le ${ }^{\mathrm{a}, b *}, \mathrm{Vu}$ Thi Kim Oanh ${ }^{\mathrm{a}}$, Nguyen Thi Minh Hanga, Huong Tran Thu ${ }^{\mathrm{c}}$, Van Minh Chau ${ }^{\mathrm{a}}$, Marc Litaudone, Van Cuong Pham ${ }^{\mathrm{a}, \mathrm{b}}$

${ }^{a}$ Advanced Center for Bioorganic Chemistry, Institute of Marine Biochemistry, Vietnam Academy of Science and Technology (VAST), 18 Hoang Quoc Viet, Caugiay, Hanoi, Vietnam;

${ }^{b}$ Graduate University of Science and Technology, VAST, 18 Hoang Quoc Viet, Caugiay, Hanoi, Vietnam;

'School of Chemical Engineering, Hanoi University of Science and Technology, 1 Dai Co Viet, Ha Ba Trung, Hanoi, Vietnam;

dInstitute of Forensic Sciences, Ministry of Public Security, 99 Nguyen Tuan, Thanh Xuan, Hanoi, Vietnam;

eInstitut de Chimie des Substances Naturelles, 91190 Gif-sur-Yvette Cedex, France;

${ }^{*}$ Corresponding author:

Assoc Prof. Dr. Huong Doan Thi Mai and Dr. Thanh Nguyen Le

Institute of Marine Biochemistry

Vietnam Academy of Science and Technology

18 Hoang Quoc Viet, Caugiay, Hanoi, Vietnam

Tel.: 842437564995

Fax: 84247917054

E-mail address: huongdm@imbc.vast.vn (Huong Doan Thi Mai);

lethanh@imbc.vast.vn (Thanh Nguyen Le) 

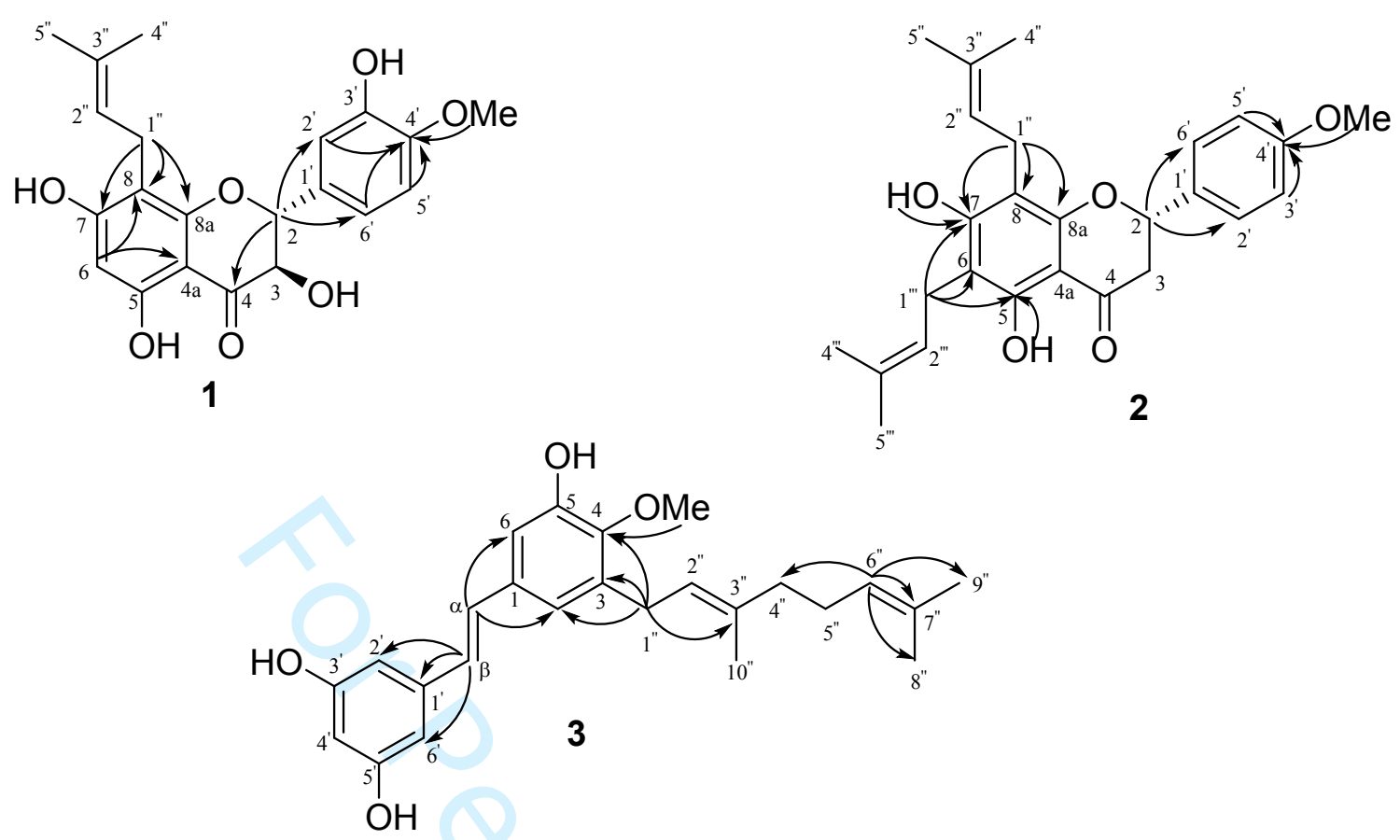

Figure S1. Key HMBC correlations of 1-3

Table S1. Cytotoxicity of isolated compounds 1-3

\begin{tabular}{cccccccc}
\hline \multirow{2}{*}{ Compound } & A549 & Hela & MCF-7 & Hep3B & Pan C1 & KB & LU-1 \\
\cline { 2 - 8 } & 29.51 & 48.98 & 53.09 & $n a$ & 64.27 & $n a$ & $n a$ \\
$\mathbf{1}$ & 10.86 & 54.95 & $n a$ & $n a$ & 7.89 & 17.84 & 22.81 \\
$\mathbf{3}$ & 26.73 & 40.09 & 50.93 & 79.43 & 54.95 & $n a$ & $n a$ \\
Ellipticine & 1.62 & 1.60 & 2.41 & 1.20 & 1.99 & 1.21 & 1.60 \\
\hline
\end{tabular}

na: not active 


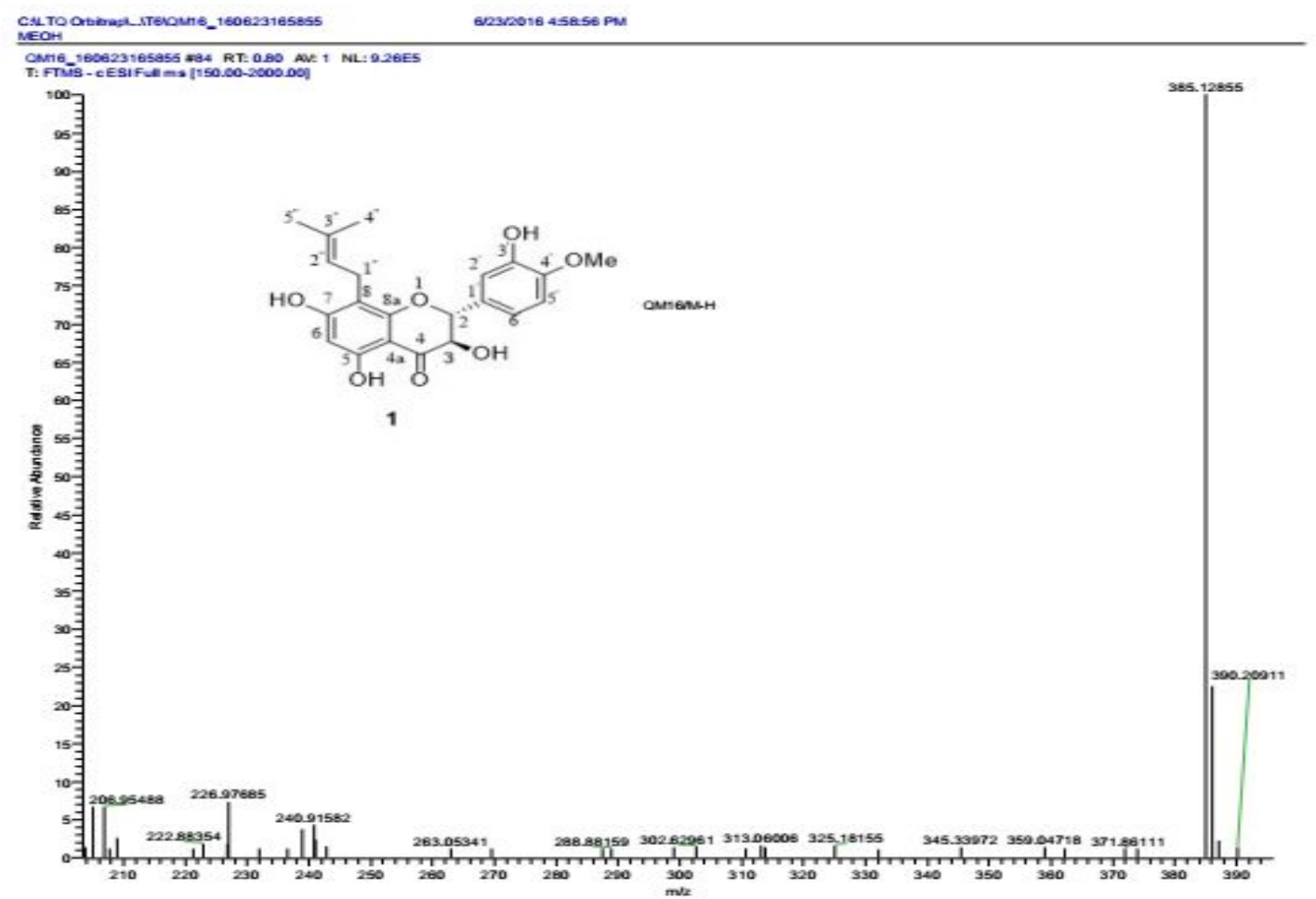

Figure S2. HR-MS spectrum of compound $\mathbf{1}$

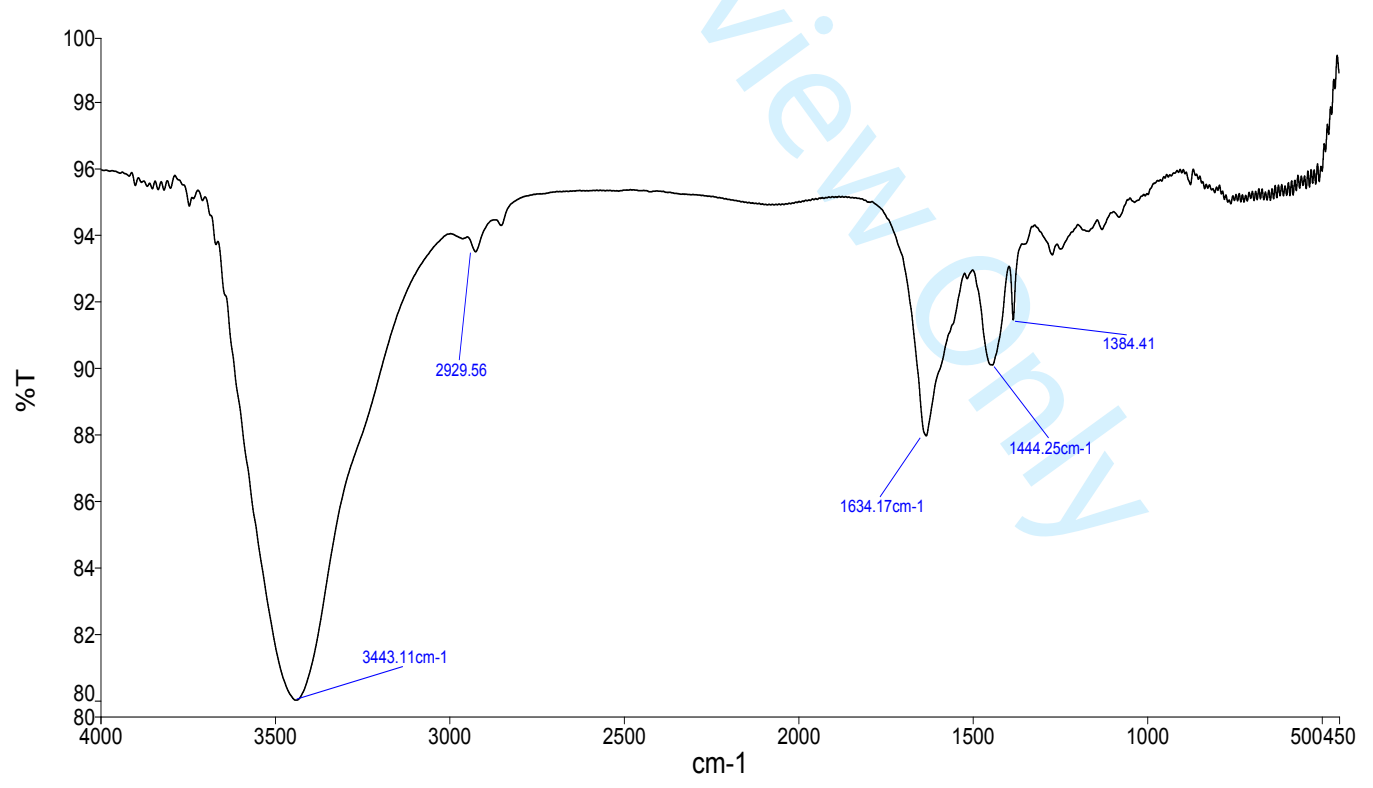

Figure S3. IR spectrum of compound 1 

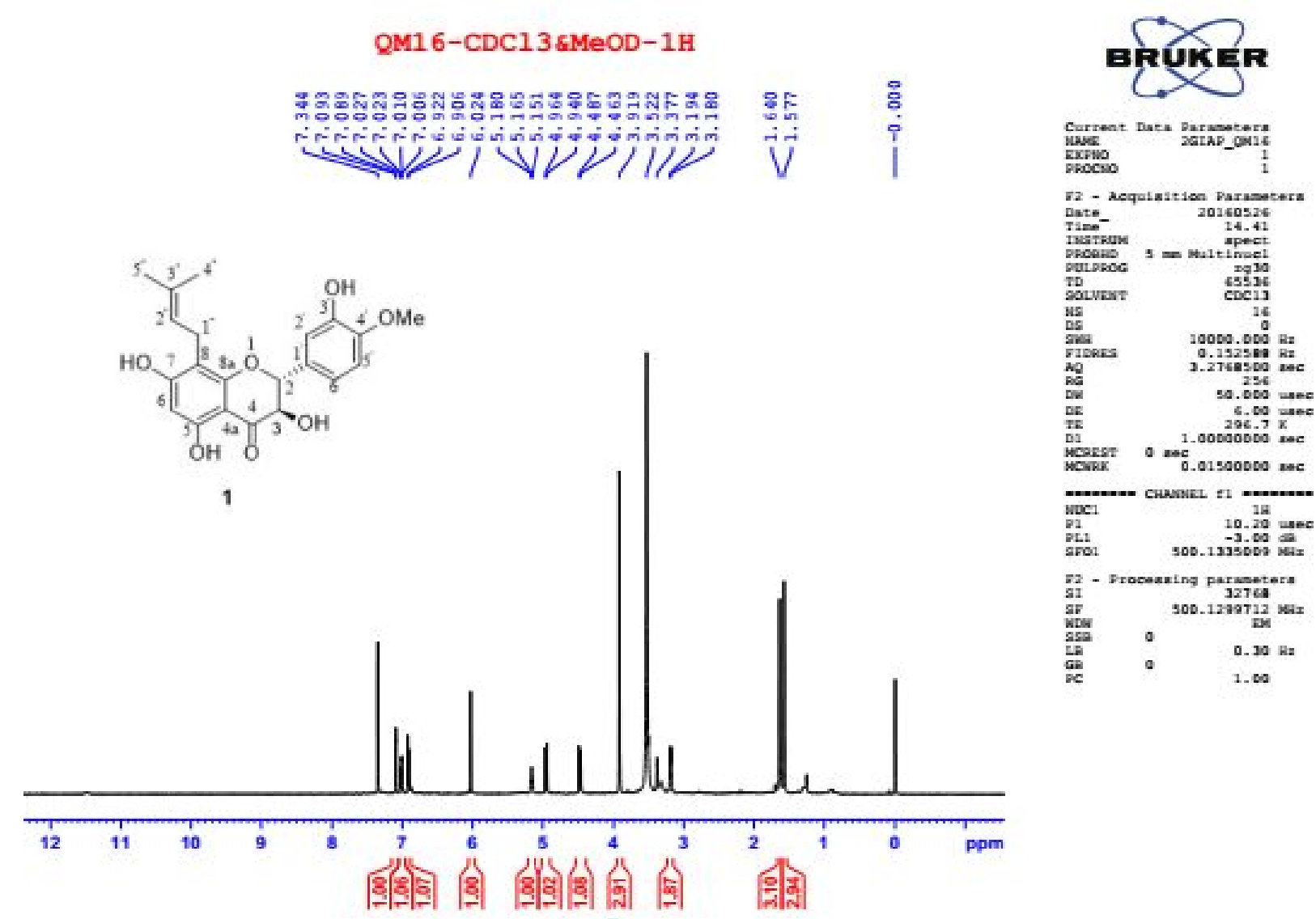

Figure S4. ${ }^{1} \mathrm{H}-\mathrm{NMR}$ spectrum of compound $\mathbf{1}$

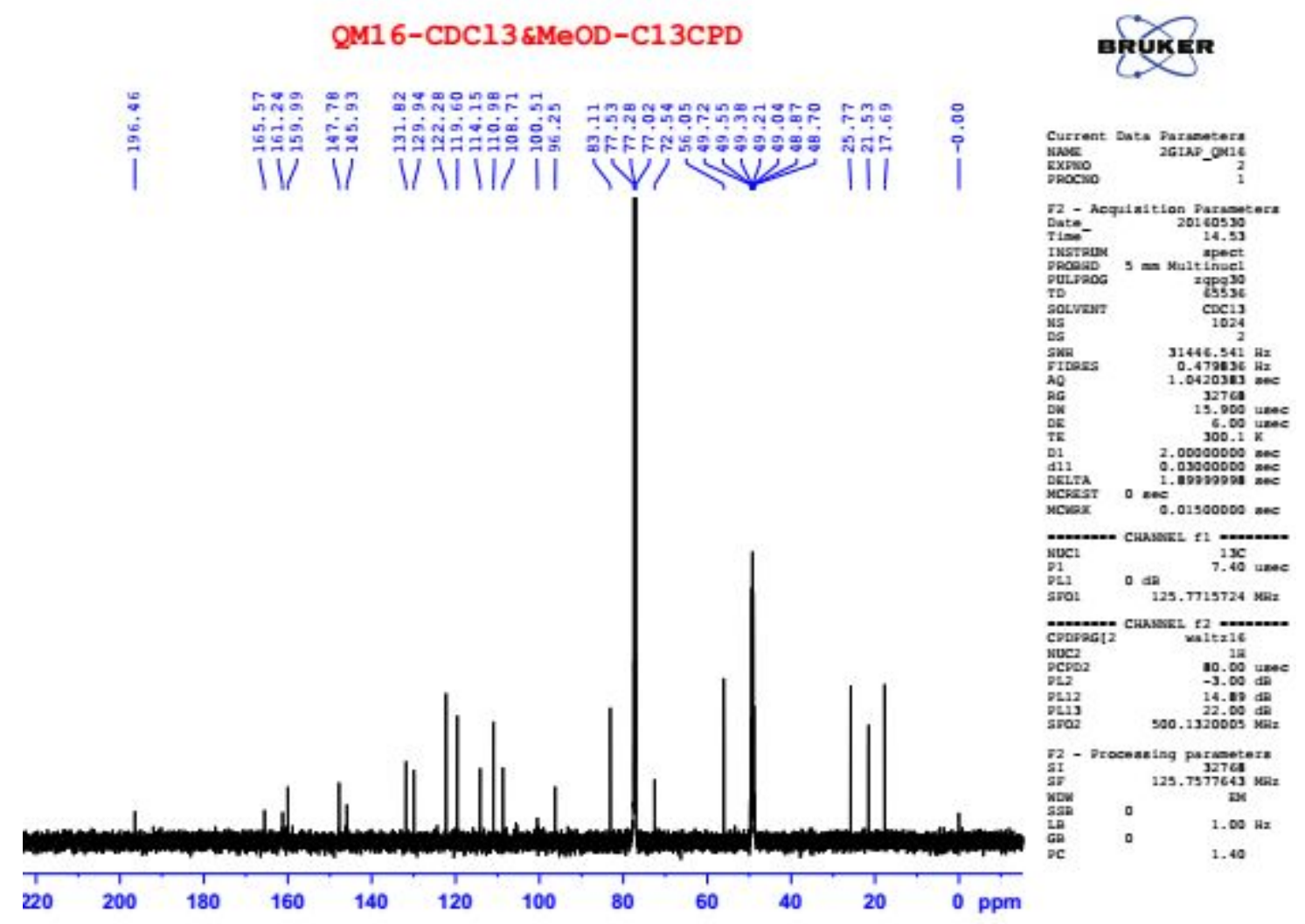

Figure S5. ${ }^{13} \mathrm{C}-\mathrm{NMR}$ spectrum of compound $\mathbf{1}$ 
DEPT 90

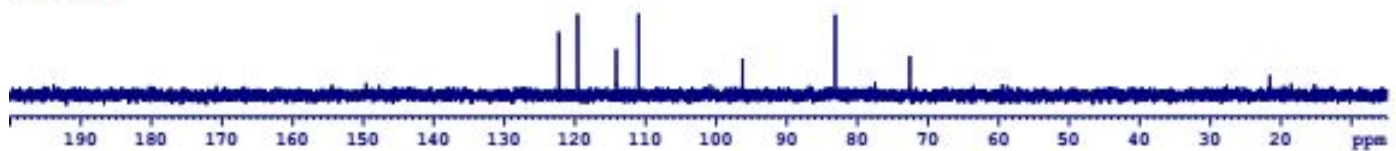

DEPT135
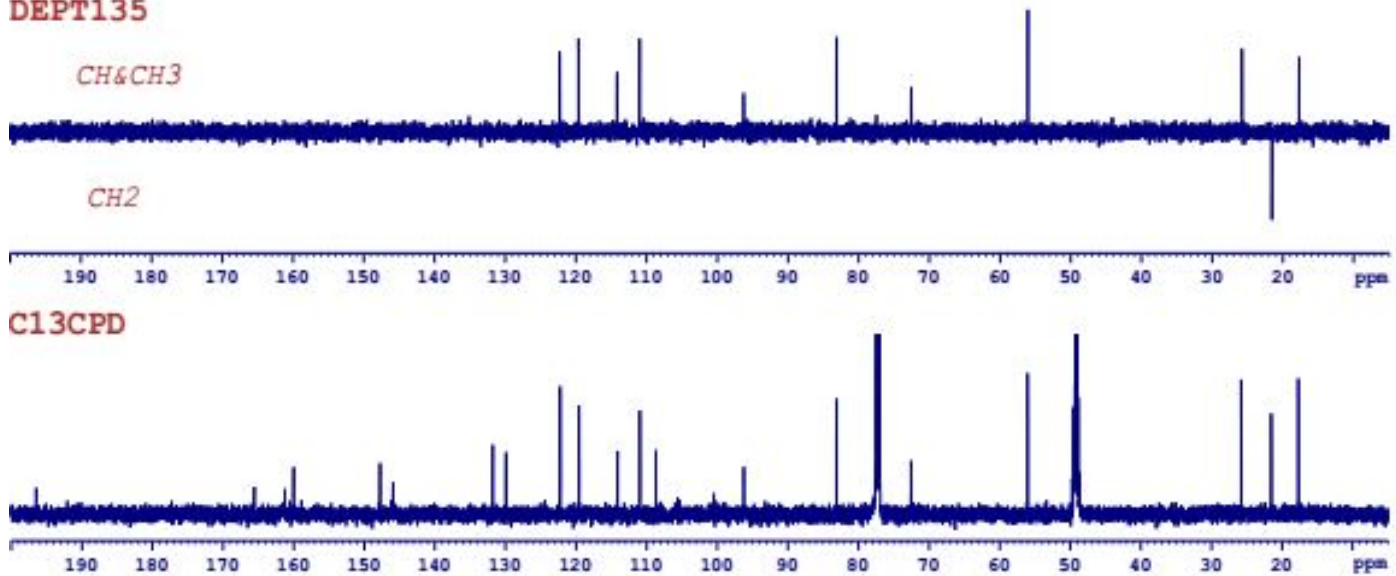

Figure S6. ${ }^{13} \mathrm{C}$-DEPT spectrum of compound $\mathbf{1}$

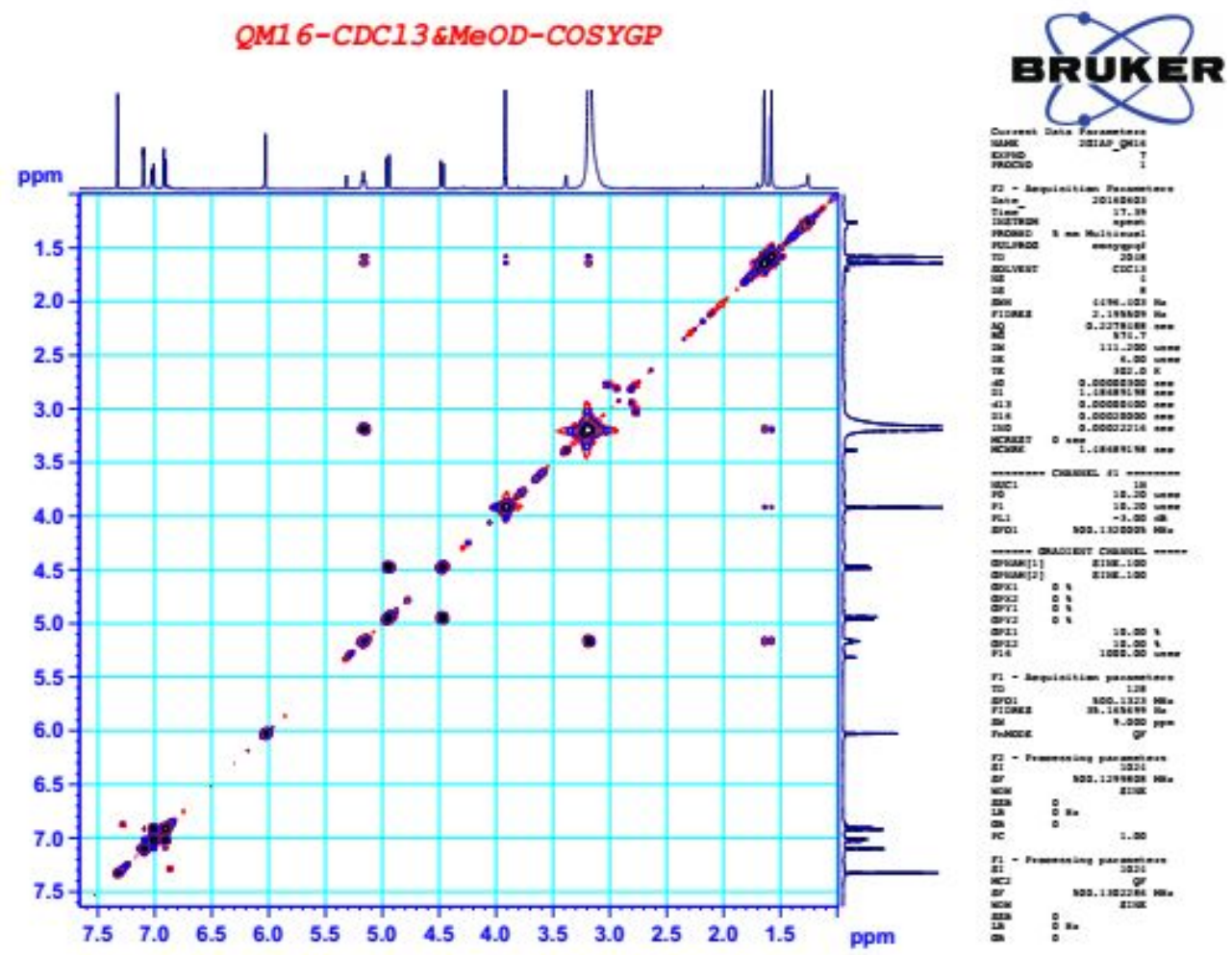

Figure S7. COSY spectrum of compound 1 


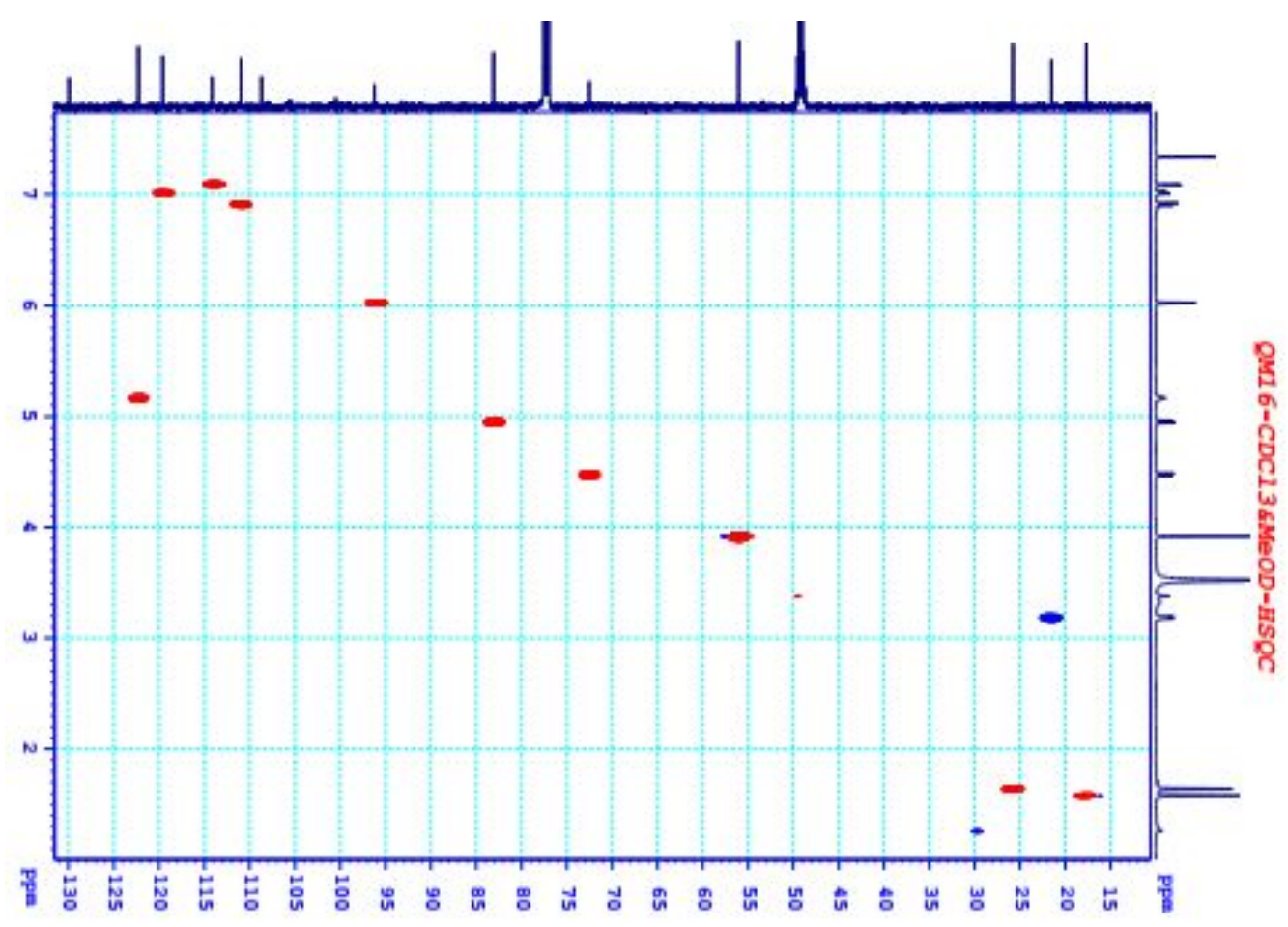

Figure S8. HSQC spectrum of compound 1

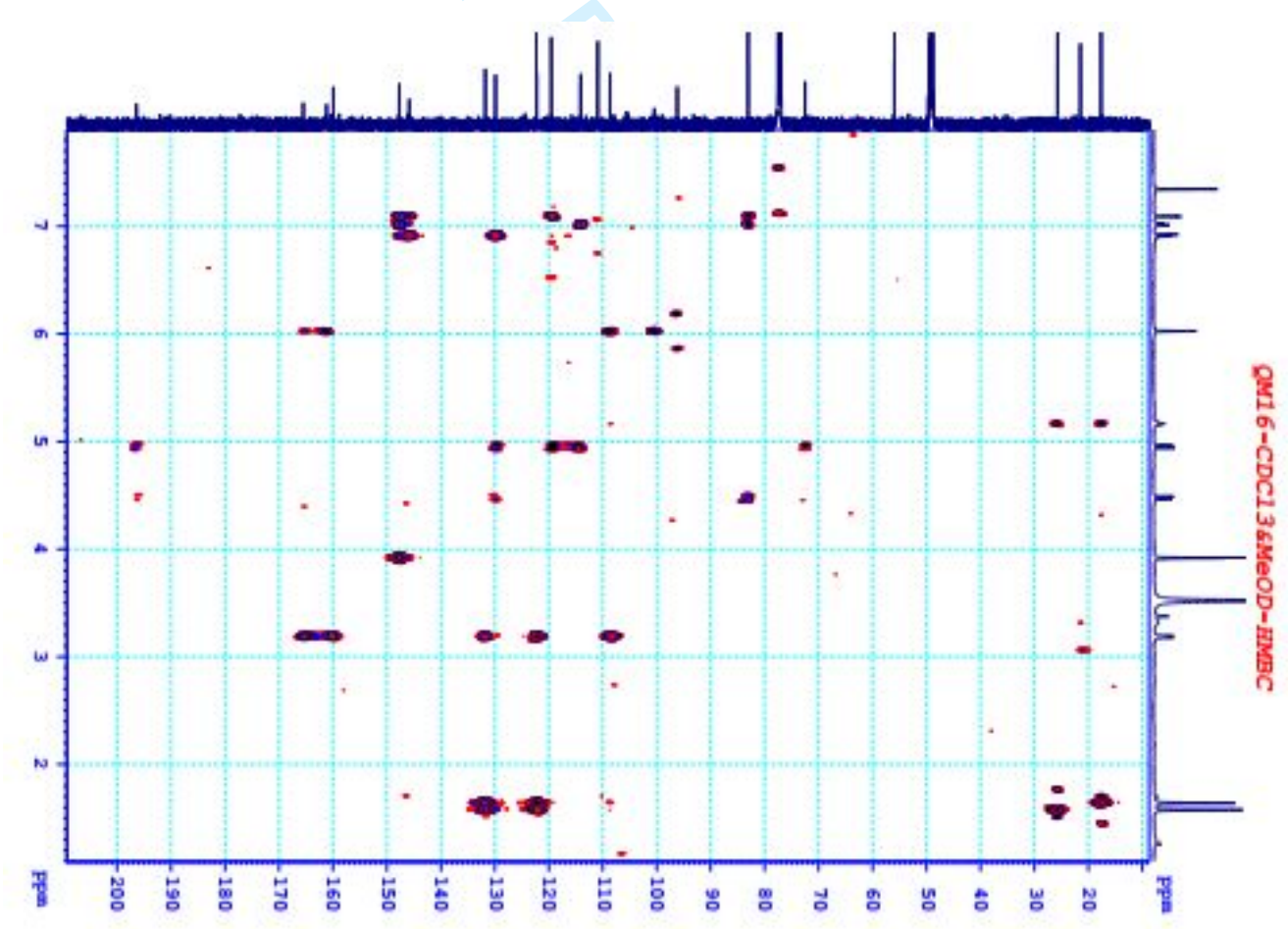

Figure S9. HMBC spectrum of compound 1 


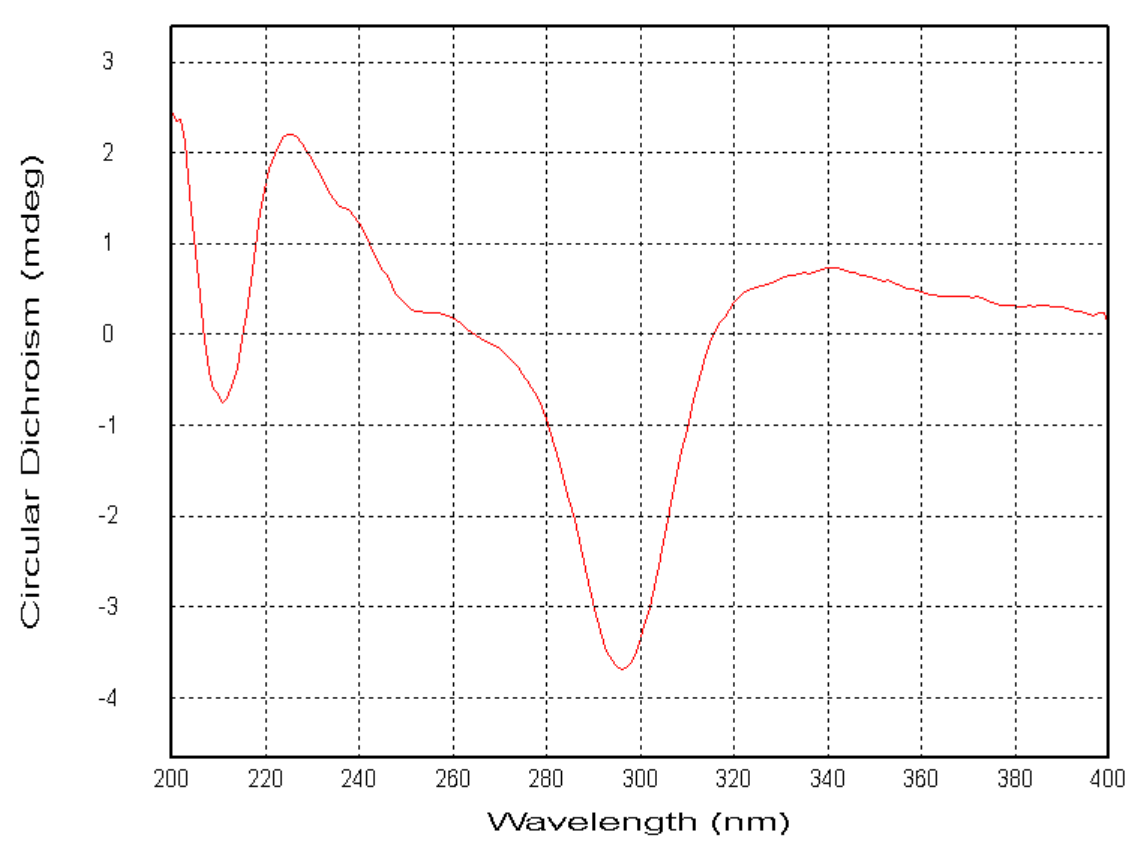

Figure S10. CD spectrum of compound 1

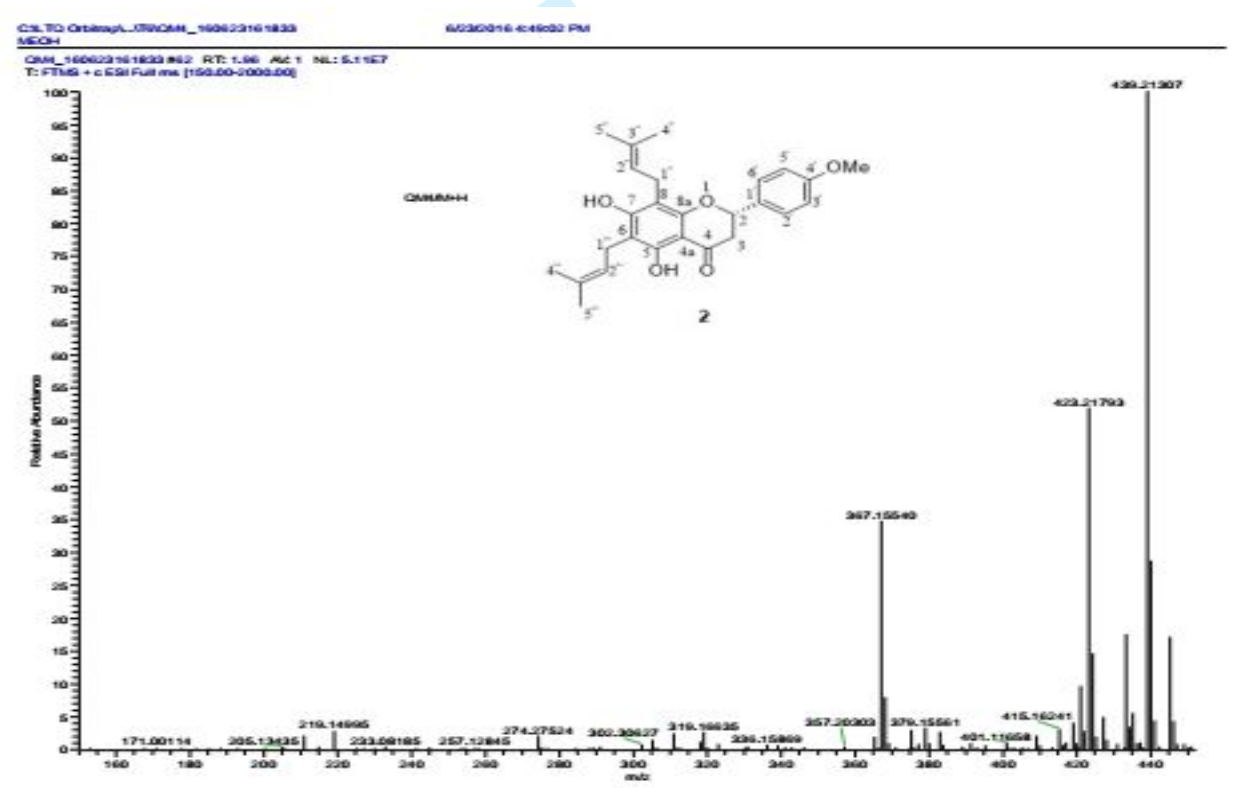

Figure S11. HR-MS spectrum of compound 2 


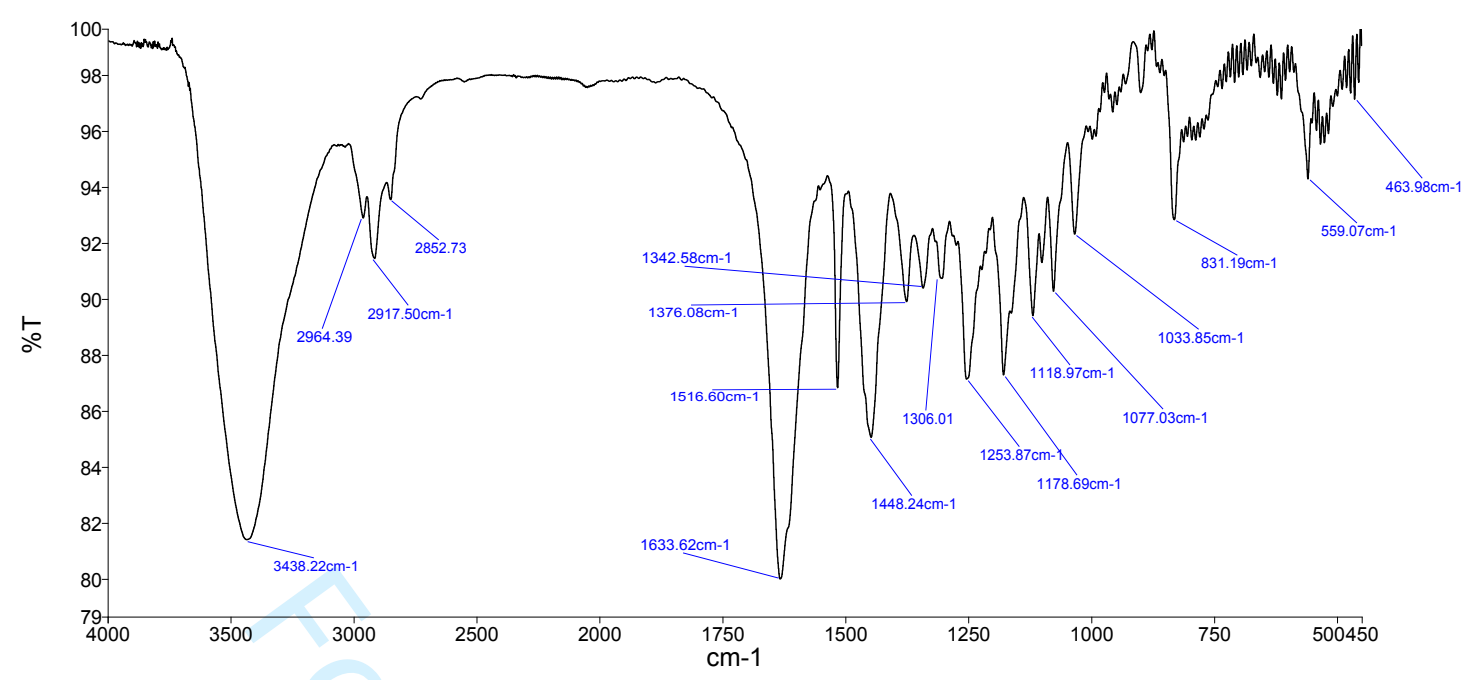

Figure S12. IR spectrum of compound 2

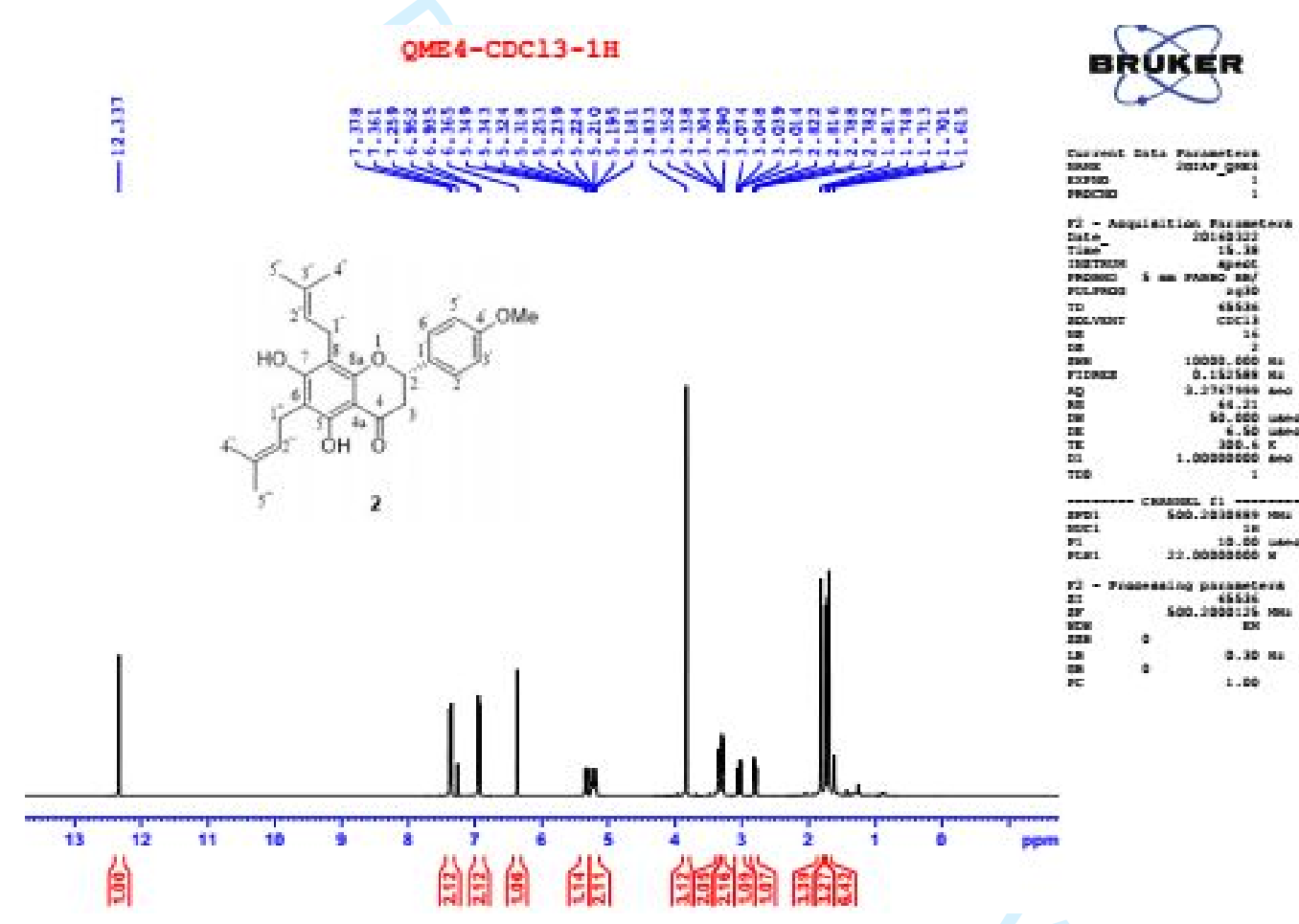

Figure S13. ${ }^{1} \mathrm{H}-\mathrm{NMR}$ spectrum of compound 2 


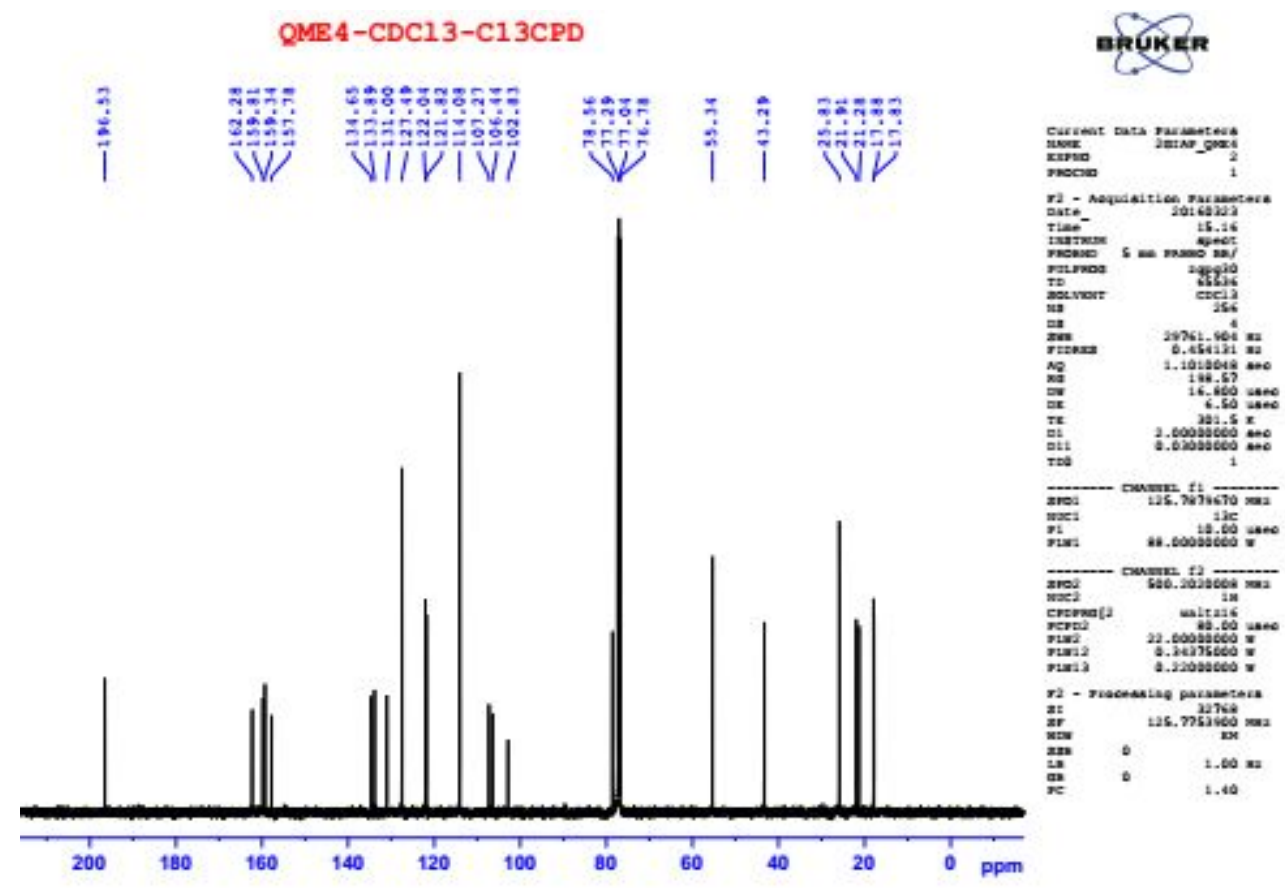

Figure S14. ${ }^{13} \mathrm{C}-\mathrm{NMR}$ spectrum of compound 2

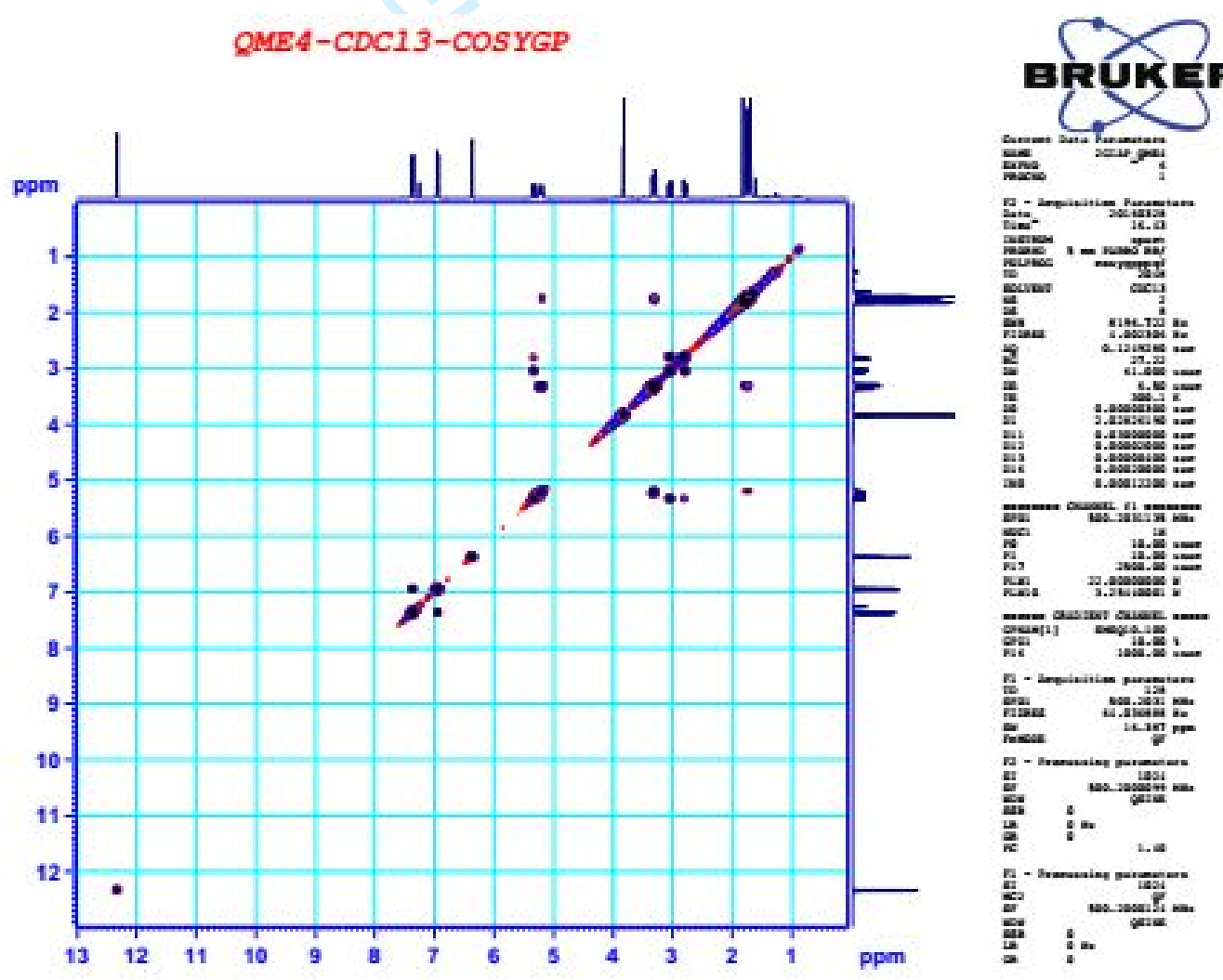

Figure S15. COSY spectrum of compound $\mathbf{2}$ 


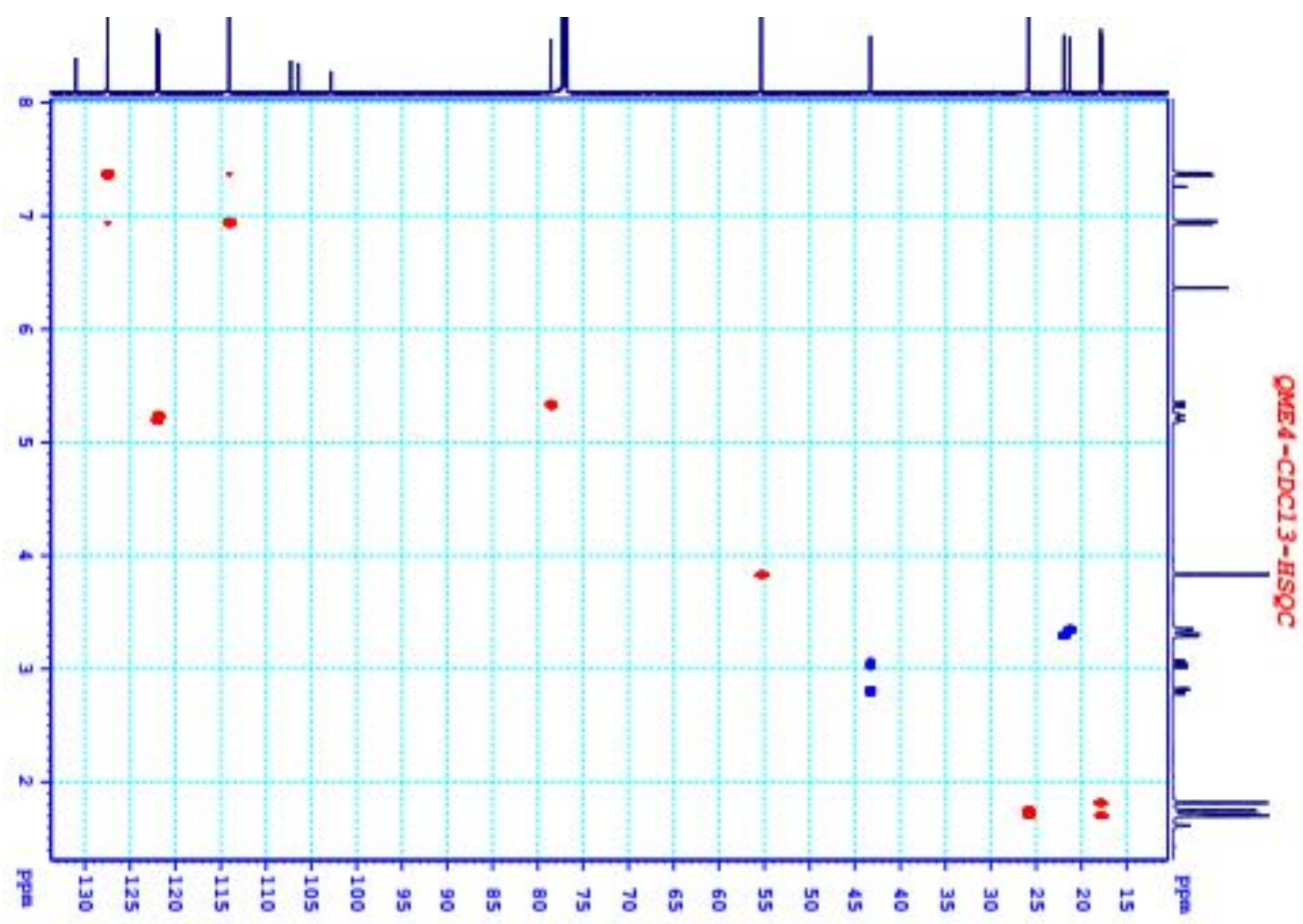

Figure S16. HSQC spectrum of compound 2

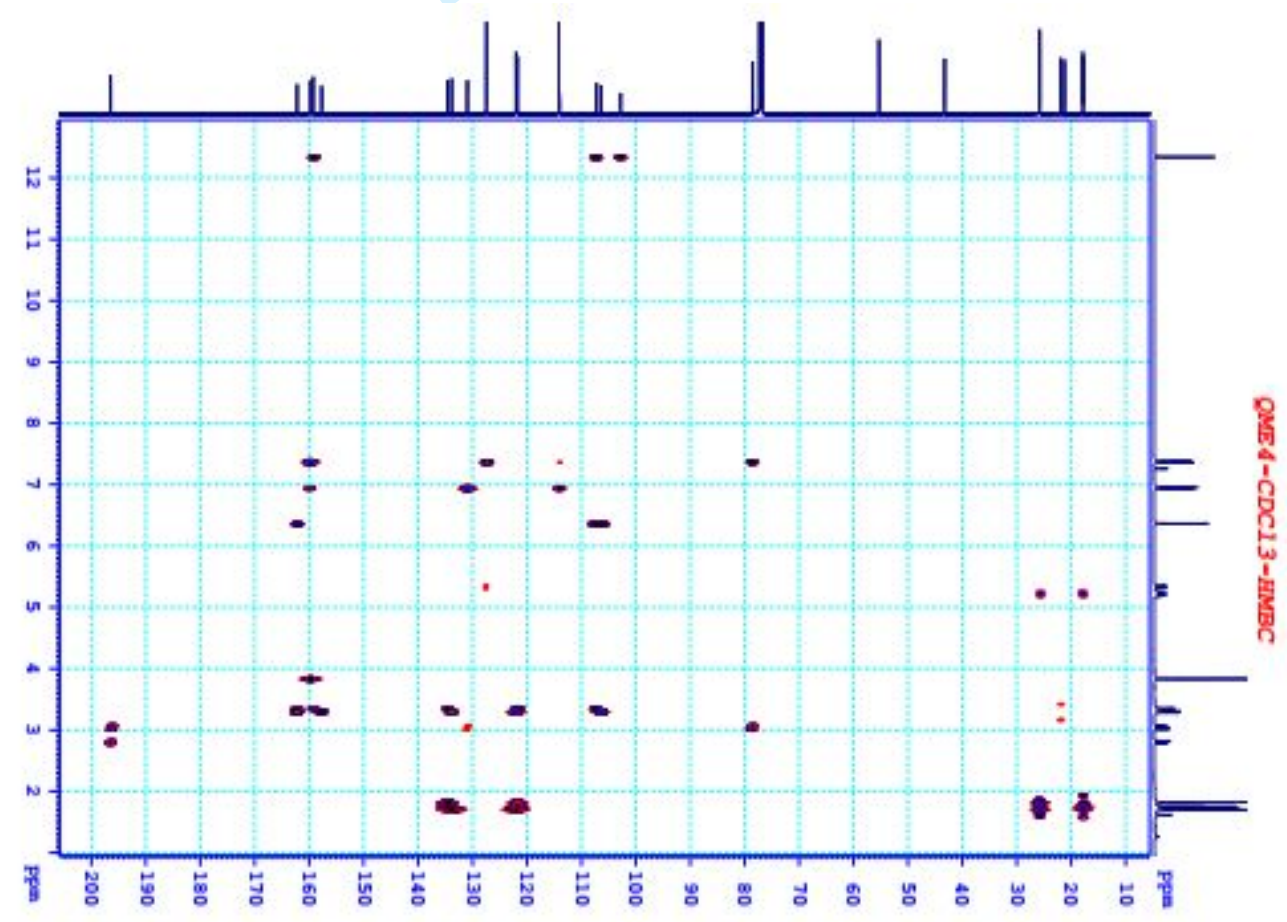

Figure S17. HMBC spectrum of compound 2 


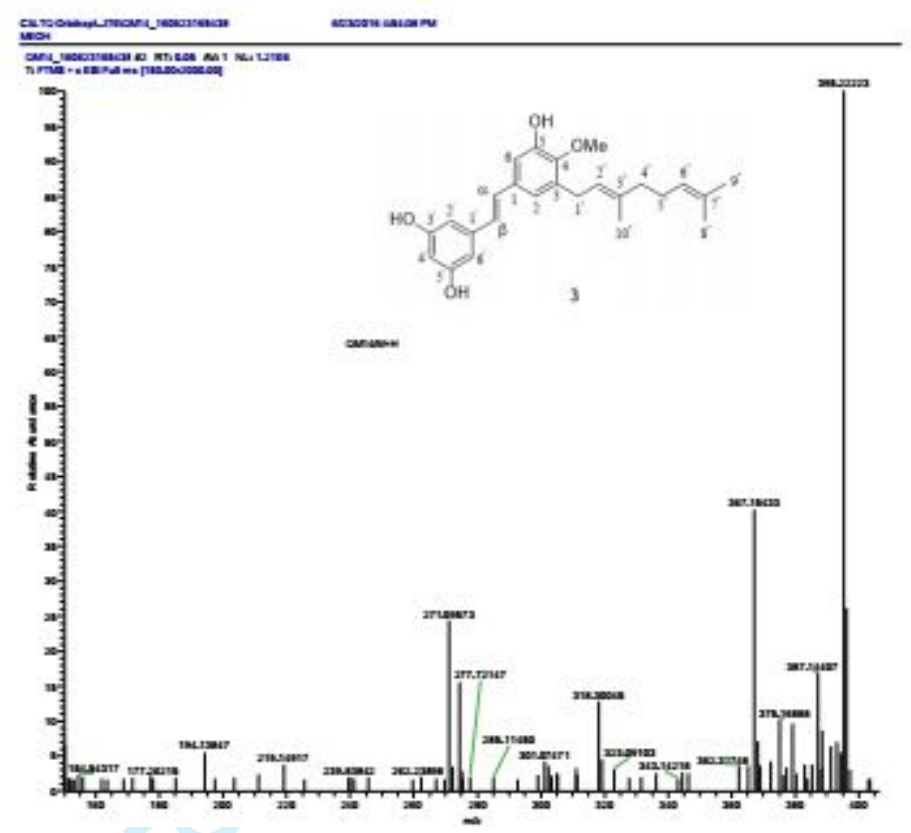

Figure S18. HR-MS spectrum of compound 3

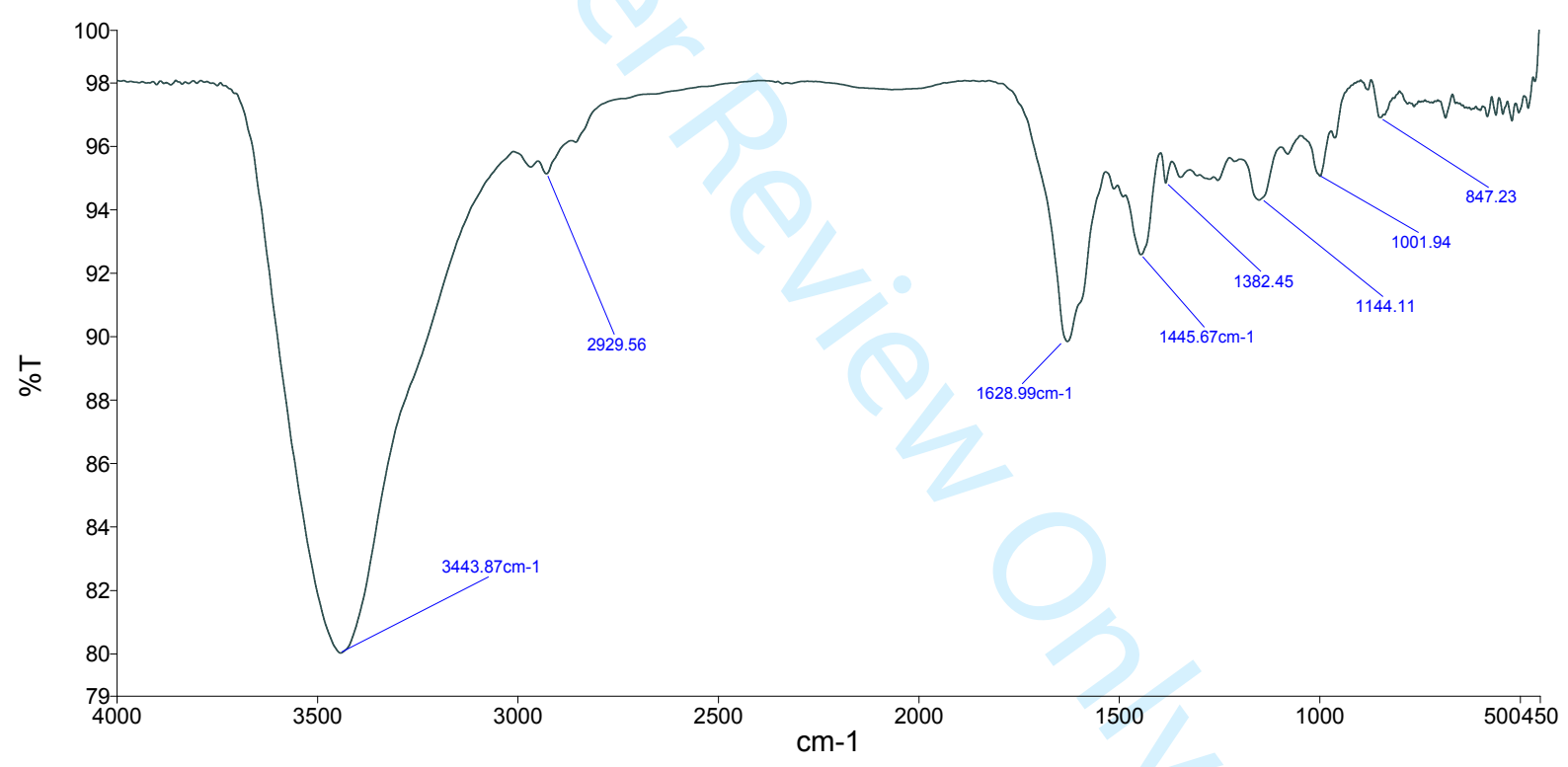

Figure S19. IR spectrum of compound 3 


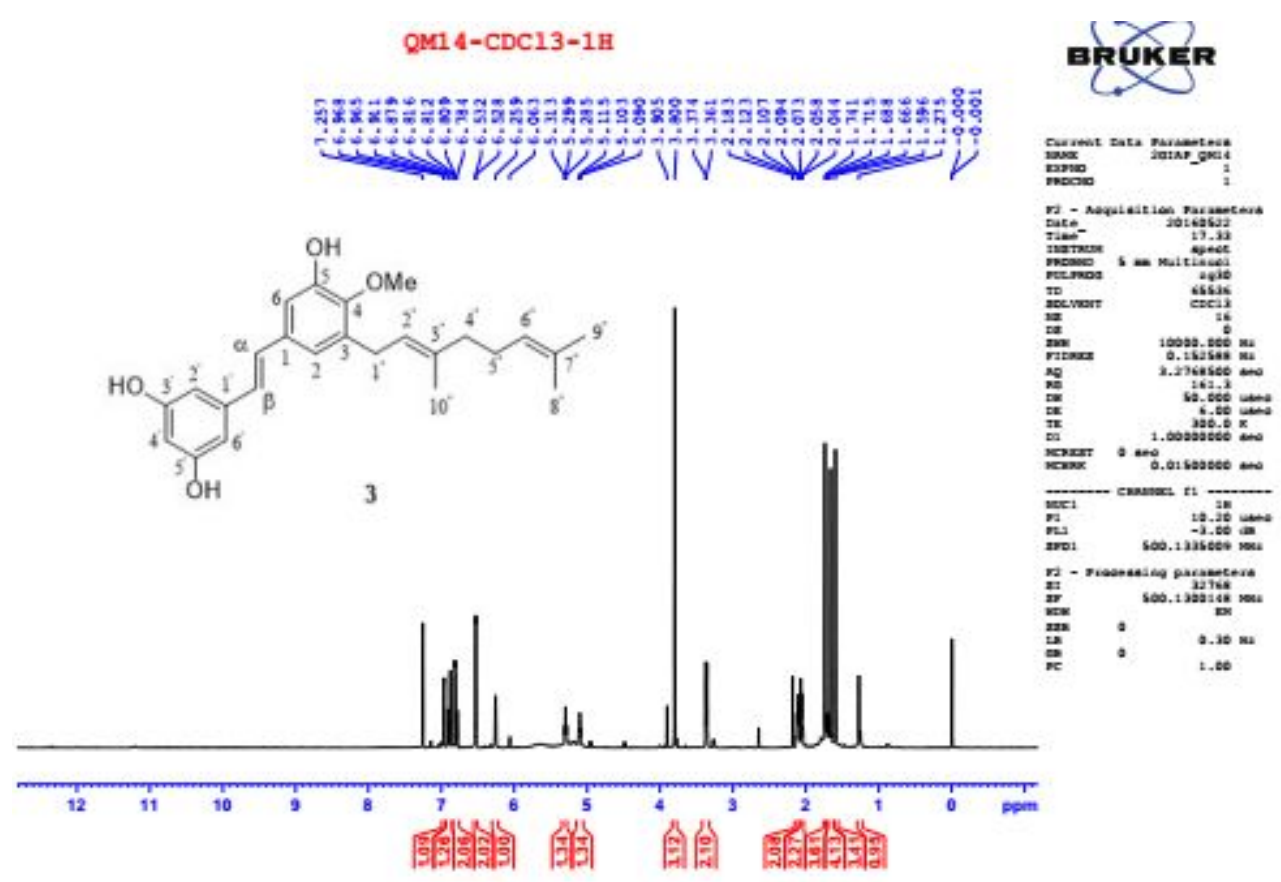

Figure S20. ${ }^{1} \mathrm{H}-\mathrm{NMR}$ spectrum of compound $\mathbf{3}$

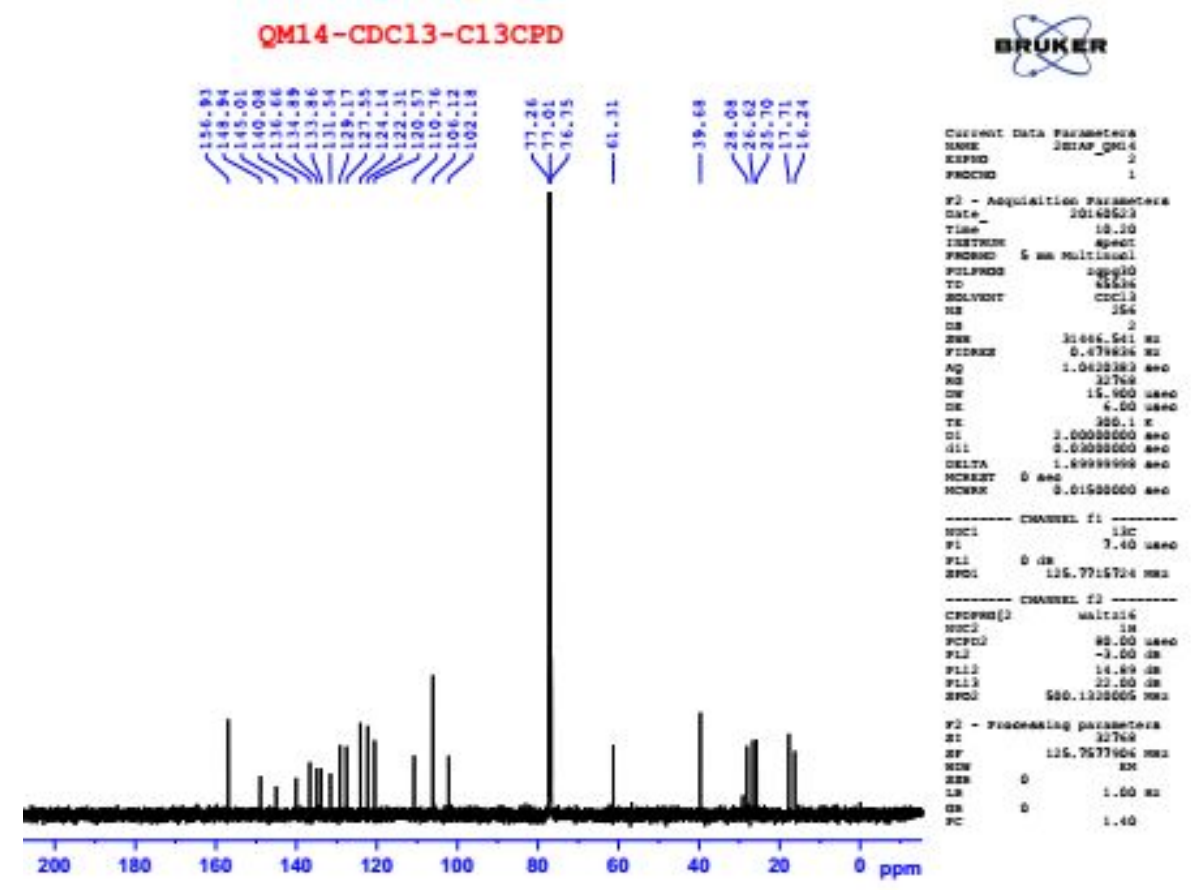

Figure S21. ${ }^{13} \mathrm{C}-\mathrm{NMR}$ spectrum of compound $\mathbf{3}$ 


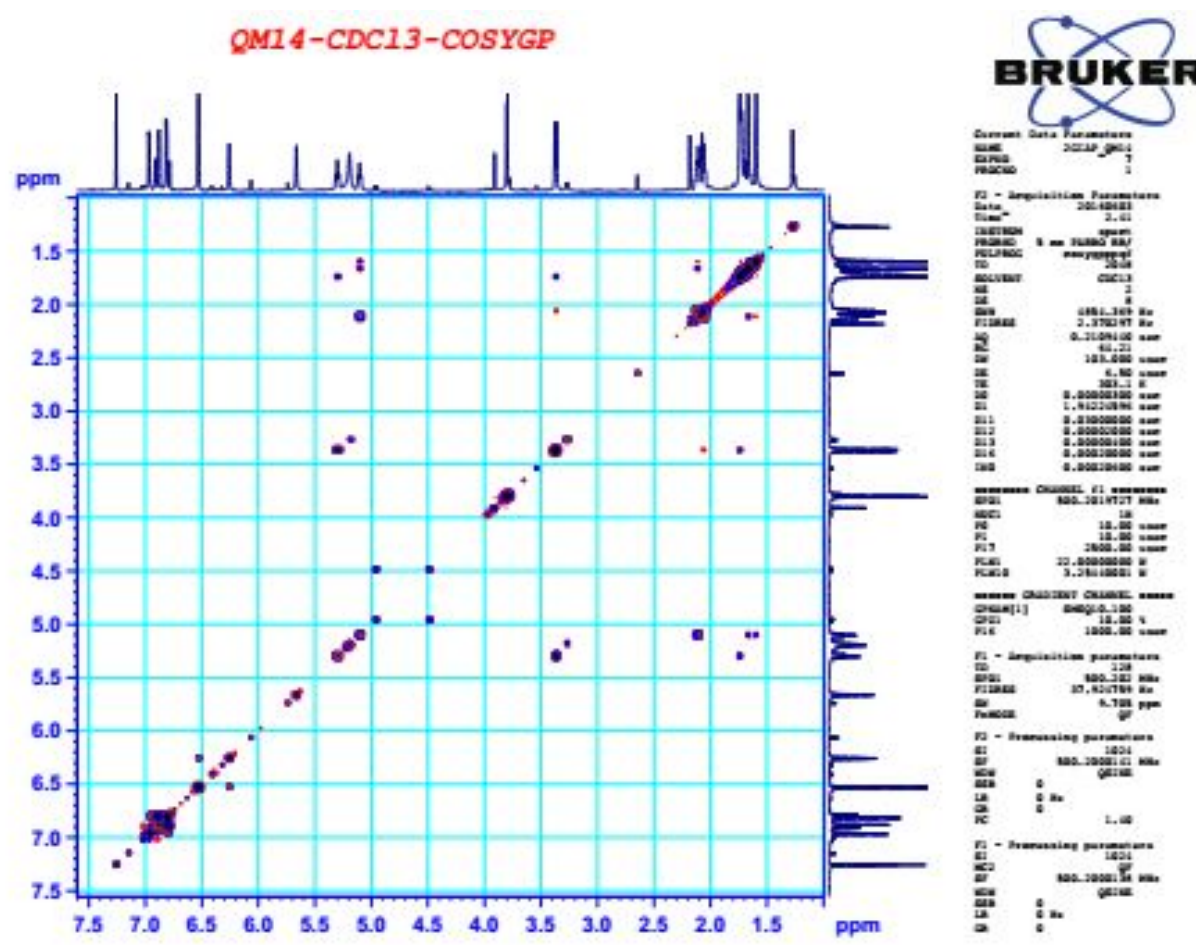

Figure S22. COSY spectrum of compound 3

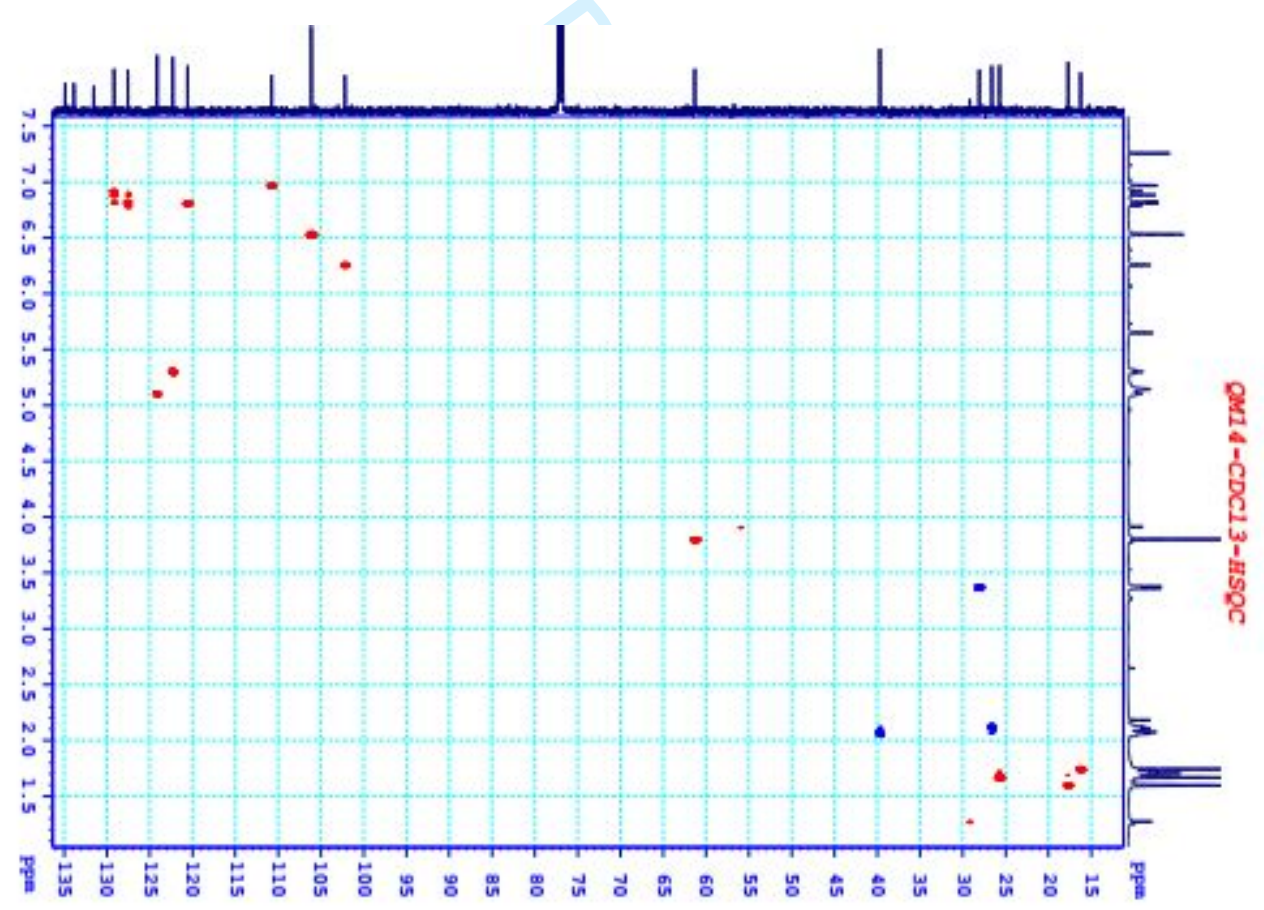

Figure S23. HSQC spectrum of compound 3 


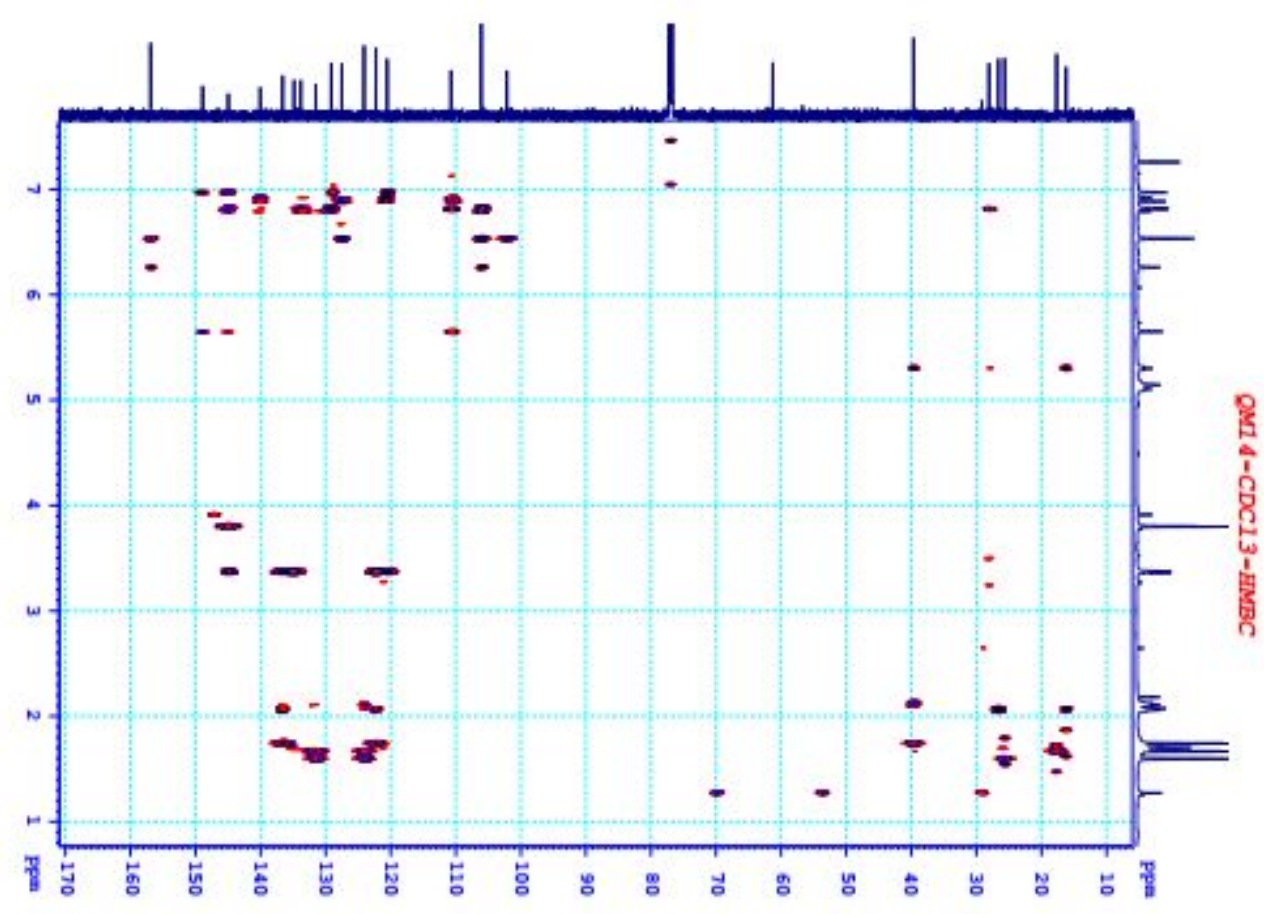

Figure S24. HMBC spectrum of compound 3 